Portland State University

PDXScholar

1979

\title{
The isolation of an individual : Thomas Mann's Tonio Kröger
}

Thomas Richard Survilla

Portland State University

Follow this and additional works at: https://pdxscholar.library.pdx.edu/open_access_etds

Part of the German Literature Commons

Let us know how access to this document benefits you.

Recommended Citation

Survilla, Thomas Richard, "The isolation of an individual : Thomas Mann's Tonio Kröger" (1979). Dissertations and Theses. Paper 2900.

https://doi.org/10.15760/etd.2898

This Thesis is brought to you for free and open access. It has been accepted for inclusion in Dissertations and Theses by an authorized administrator of PDXScholar. Please contact us if we can make this document more accessible: pdxscholar@pdx.edu. 
AN ABSTRACT OF THE THESIS OF Thomas Richard Survilla for the Master of Arts in German presented June 29, 1979.

Title: The Isolation of an Individual: Thomas Mann's Tonio Kroger.

APPROVED BY MEMBERS OF THE THESIS COMMITTEE:

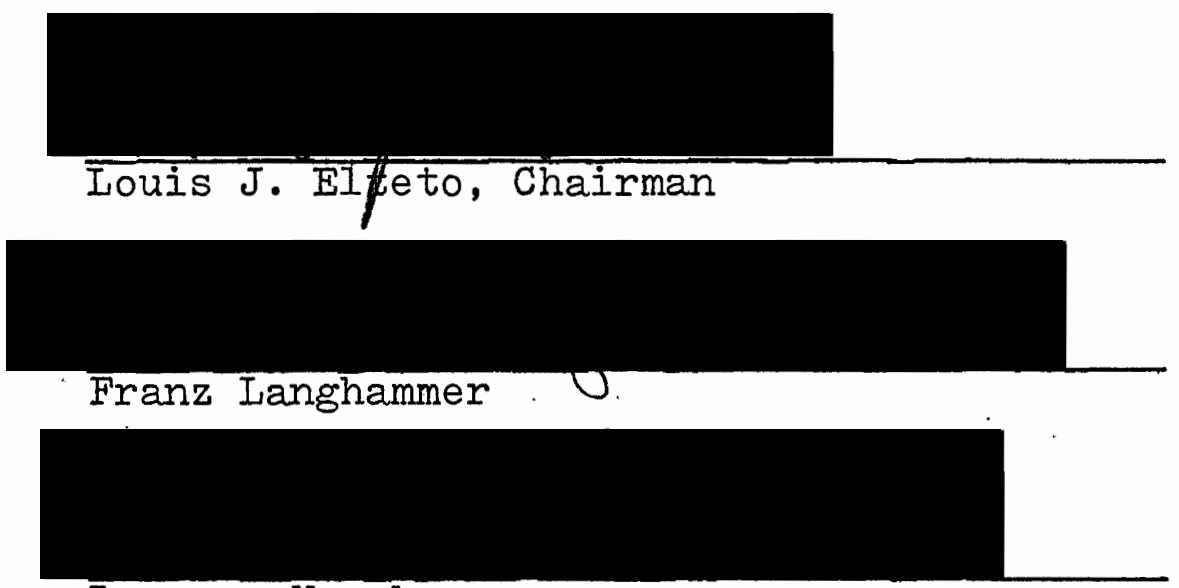

Laureen Nussbaum

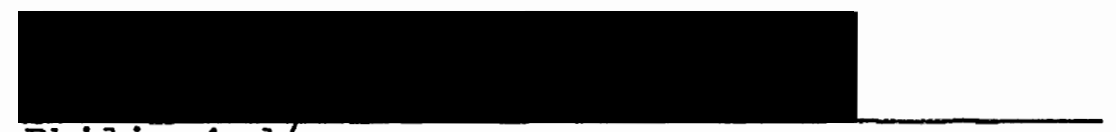

Philip Anderson

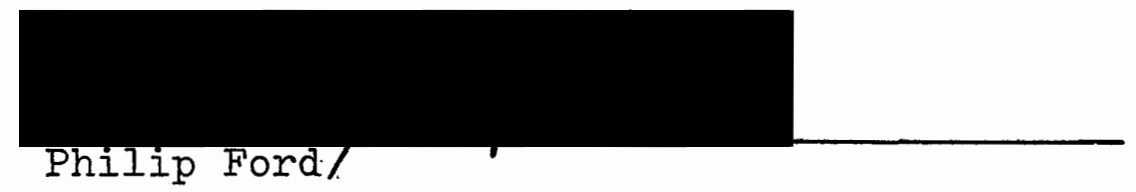

Thomás Mann, early in life, felt himself to be "different" from others around him and "isolated" from the normal life that others enjoyed. He attributed these feelings to what he felt was his descent from a sound Burger life to unsound Kunstlertum. 
These feelings of guilt and suffering prodded Mann into applying his introspective artistic techniques to his own condition. He examined his own life, considered his own' world and his relationship to it, and came to certain conclusions. Many of Mann's works are therefore not "fiction" at all; he himself once stated that all of his works were autobiographical.

Mann's works were concerned with the problem of art and Kunstler versus life. A Kunstler must "isolate" himself from life in order to create. It is a prerequisite of artistic creation that one must "step back from life" and examine it coolly and dispassionately, and not sentimentally, in order to portray it most accurately. The Kunstler undergoes aesthetic experiences, "sees" the universal in the particular, and "shapes" it into art. Nevertheless, the danger exists that the Kunstler will pass beyond this, will apply his introspection not only to his work, but also to his life. When he does this, he can easily be overcome by the feeling that he is a failure as a human being--that his special talents as a Kunstler have not given him the opportunity to participate in life, but only to observe it. The Kunstler who reaches this stage often uses his introspective techniques to overcome his sufferings and to re-emerge on the path to Humanization. Thus the works termed "Kunstlerroman" are an explanation of more than the relationship of the Kunstler to society. They are a clear picture of how it feels to be "different" from those around 
you--how it feels to be an isolated individual.

Like all authors, Thomas Mann wrote from experience, and his experiences were of feeling that he had been cut off from normal experiences. Golo Mann writes that his father's clearest youthful self-portrait is Tonio Kroger. Within this Novelle, Thomas Mann describes Tonio's isolation not only as a kunstler, but also as a human being. Tonio, like his creator Thomas Mann, feels himself separated from the rest of the Burger/Kunstler world. He is an "isolated individual."

The isolated individual suffers because he views the world differently; he "feels" experiences more deeply and "sees" the universal in the particular far more often than the non-introspective individual. How such an individual is able to overcome his suffering in order to live a full life is the subject of Tonio Kryger and is the theme of this paper. The conclusion is a recognition that one's own individuality is a part of a greater universality, and the feeling of being "different" is a valid position, not something to be feared. This awareness separates the isolated individual at last from the nothing-but-Burger and the nothing-but-Kunstler, but at the same time it draws him into a further unity, where even the isolated individual can lead a full, rich, rewarding and satisfying life. 
THE ISOLATION OF AN INDIVIDUAL

Thomas Mann's Tonio Krögex

by

THOMAS RICHARD SURVILLA

A thesis submitted in partial fulfillment of the requirements for the degree of

MASTER OF ARTS

in

GERMAN

Portland State University

1979 
TO THE OFFICE OF GRADUATE STUDIES AND RESEARCH:

The members of the Committee approve the thesis of Thomas Richard Survilla presented June 29, 1979.

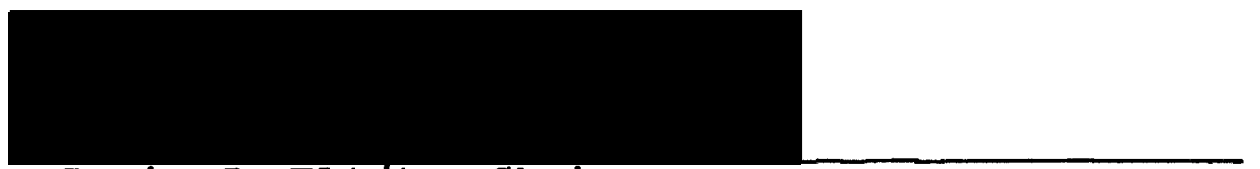

Louis J. Elteto, Chairman

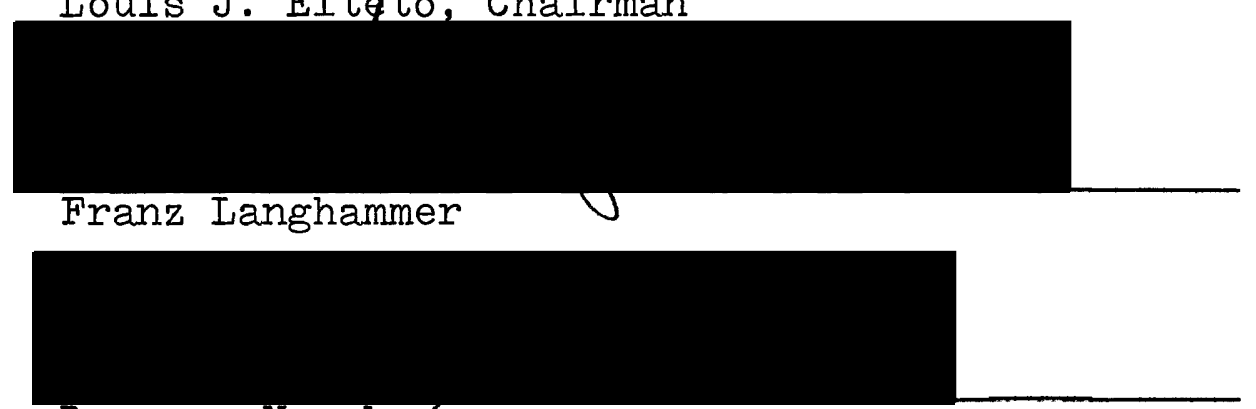

Laureen Nussbaúm

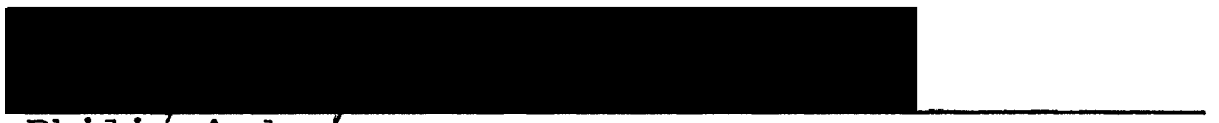

Philip Anderson

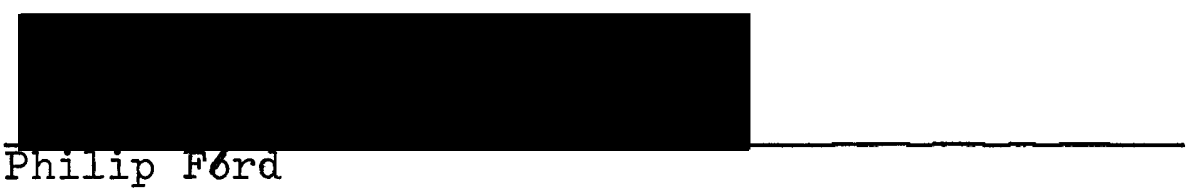

\section{APPROXED:}
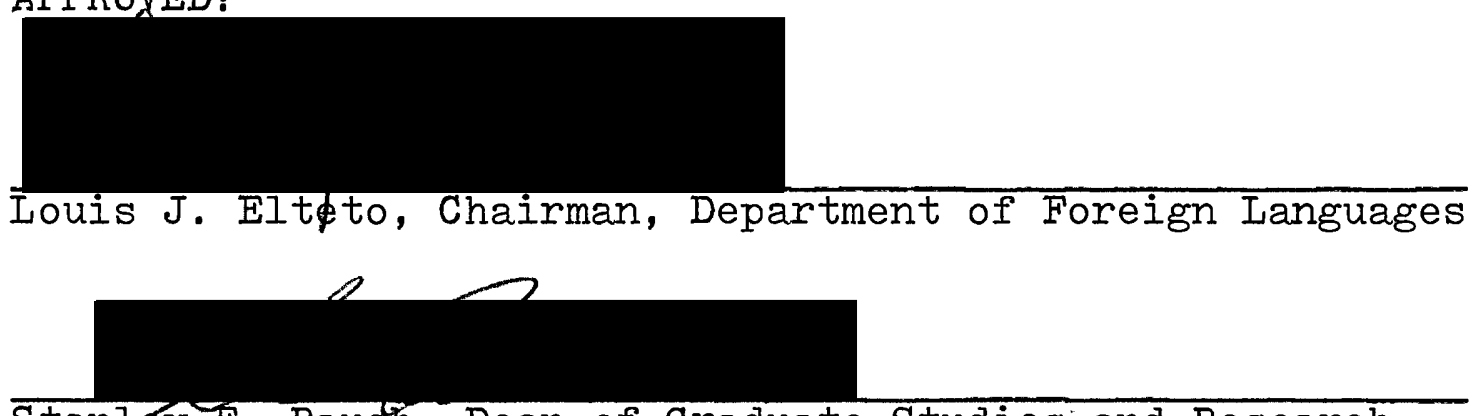

Stanley E. Rauch, Dean of Graduate Studies and Research 
TABLE OF CONTENTS

PAGE

CHAPTER

I INTRODUCTION . . . . . . . . . . . . . I

II THOMAS MANN AND TONIO KRÖGER . . . . . . . 24

III THE WORLD OF TONIO KRÖGER . . . . . . . . 32

IV THE ORIGINS OF ISOLATION . . . . . . . . . 50

$\mathrm{V}$ THE REBIRTH OF TONIO KRÖGER . . . . . . . 67

VI CONCLUSIONS . . . . . . . . . . . 84

BIBLIOGRAPHY . . . . . . . . . . . . . . . . . 94 
CHAPTER I

INTRODUCTION

FAUST. Du bist dir nur des einen Triebs bewußt, - lerne nie den andern kennen:

Zwei Seelen wohnen, ach: in meiner Brust, die eine will sich von der andern trennen;

die eine hält, in derber Liebeslust, sich an die Welt, mit klammernden Organen;

die andre hebt gewaltsam sich vom Dust

zu den Gefilden hoher Ahnen.

What is the relationship of the individual to society? Our occidental philosophical traditions have implanted in us a two-pole view of our world. Our lives are guided and ruled by these "two souls within our breasts": everything is black/white, up/down, good/bad. We are so driven by this unconscious division that we are disturbed by the uncategorizable. If something comes along that by its nature belongs to both groups, we feel uncomfortable, threatened; it cannot belong to both. We deny the elements that are not of our own group. We negate them or we ignore them, and then again we feel comfortable. We are so accustomed to this black/white categorizing that we find it difficult, if not impossible, to imagine that something "gray" could be true and valid.

We tend to forget, as Hermann Hesse wrote, "Wenn ich sage «Oben» oder «Unten», so ist das ja schon eine Behauptung, welche Erklärung fordert, denn ein Oben und Unten gibt es 
nur im Denken, nur in den Abstraktion. Die Welt selbst kennt kein Oben noch Unten."1 Instead, we categorize. One is a soldier; one is a civilian. One is a respectable Bürger; one is a Künstler. We have pre-conceived notions: certain behavior, certain desires and drives belong only in certain categories. We expect them, we observe these expectations, and we live within the confines of the category.

But what happens when the world diverges from our expectations? We have a picture of life within us, a "genuine reality," and gradually we discover that the world is not ideal, that no pre-conceived notions will actually match what we find in life. We have ideals, and we find that the world actually expects far less from us than we demand from ourselves. Some, those who shun intense experience and absolute positions, find this extremely comforting and rapidly adapt to this apparent world. For certain others, this "so-called reality" is intensely disappointing. As Goethe has written in his autobiography,

Denn wie man wohl den Entschluß faßt, soldat zu werden und in den Krieg. zu gehen, sich auch mutig vorsetzt, Gefahr und Beschwerlichkeiten zu ertragen sowie auch Wunden und Schmerzen; ja den Tod zu erdulden, aber sich dabei keineswegs die besonderen Fälle vorstellt, unter welchen diese im allgemeinen erwarteten Übel uns äußerst unangenehm überraschen können: so ergeht es einem jeden, der sich in die Welt wagt. 2

1 Hermann Hesse. Steppenwolf, in Gesammelte Schriften (Frankfurt: Suhrkamp, 1957), IV, 241-42; hereafter cited G.S.

2 Johann Wolfgang von Goethe, Dichtung und Wahrheit, in Goethes Werk (Hamburg: Christian Wegner, 1957), IX, 574. 
How does one handle life's disagreeable surprises? How does one handle disappointment with this "so-called reality?" One examines again his categorized world and attempts to reconcile the differences between the two "realities." One of them must be an actual "Seinwelt"; the other must be only a "Scheinwelt." Disappointment in life often convinces the surprised one that his own world view has been false. The world must be right and he must be wrong. Where does he then turn?

Those who have reached this point are struggling with the dichotomies of life, and solutions are not clear-cut. The only reassurance comes from learning that the struggle is not new, that one's search for understanding is not unique. For those searchers, literature can help, not by providing simple. solutions, but by showing that the long, tortuous path to self-understanding has been trod by many others.

Henrik Ibsen said, "All that moves me, all that I experience, is material for my poetry. . . ."3 If literature, then, can reflect the experiences of life, we can expect to find literary representations of the artist's own struggle with the dichotomies of life. Such sketches we do find, especially with Thomas Mann and Hermann Hesse. Max Schmid asserts, "The struggle with the basic

3 Henrik Ibsen, speech in April 1891, trans. Lois Miles, as quoted in A.E. Zucker, Ibsen: The Master Builder (New York: Henry Holt, 1929), p. 237. 
problem of his existence, with the dichotomy of intellect and soul. . leads the poet to a bio-centric vision of the world in place of that logo-centric vision that has dominated the attitude of the modern European since the Renaissance." 4 Such a vision is visible in the works of both Mann and Hesse. Mann, like his hero Tonio Krbger, considered himself "ein Burger, der sich in die Kunst verirrte, ein Bohemien mit Heimweh nach der guten Kinderstube, ein Kunstler mit schlechtem Gewissen." 5 And Hesse expounds in his Kurgast:

Ich mbchte einen Ausdruck finden fllr die Zweiheit, ich mochte Kapitel und Satze schreiben, wo bestandig Melodie und Gegenmelodie gleichzeitig sichtbar wären, wo jeder Buntheit die Einheit, jeden Scherz der Ernst bestandig zur Seite steht. Denn einzig darin besteht fur mich das Leben, im Fluktuieren zwischen zwei Polen, im Hin und Her zwischen den beiden Grundpfeilern der Welt. Bestandig mochte ich mit Entzlicken auf die selige Buntheit der Welt hinweisen und ebenso bestandig darin erinnern, dass dieser Buntheit eine Einheit zugrunde liegt.

To express this struggle with the dichotomies of life, the author must necessarily have a hero who is "different," who is set apart from the masses. Both Hesse and Mann wrote stories with such heroes. Their characters are "different" because they spend a good deal of time thinking and worrying about their relationship to life and society. Moreover,

4 Max Schmid, Hermann Hesse (Zurich: Fritz and Wasmuth, 1947), p. 223 .

5 Thomas Mann, Tonio Kryger, in Gesammelte Werke in zwolf Banden (Oldenburg: S. Fischer Verlag, 1960), VIII, 337; hereafter cited as G.W.

6

Hesse, G.S., IV, pp. 113-114. 
these heroes, like their authors, are Künstler, because it is the Künstler's task to examine life, to come to some conclusion, and to express that conclusion in artistic form. The Künstler, because of his calling, is one who is "different."

An examination of the works of either Mann or Hesse will aid those others who are searching for an understanding of life, who are struggling with the dichotomies of life. Nevertheless, there is a distinct difference between the works of these two men. Thomas Mann focuses his attention first on the isolation of the Künstler, the problems inherent in the artistic life, and thence speaks of the relationship of the individual to society as a whole. Hermann Hesse makes far more personal statements. His characters--Veraguth, the artist, Harry Haller, the editorial writer, etc.--are often Künstler, but their struggles are with life, not with art.

The danger in attempting literary representations of one's own personal search for the meaning of life is just this: it is, indeed, personal. As such the works will succeed only if they can strike a personal note in the mind of the reader. Hesse understood this, and in a reply to a request from the publisher Samuel Fischer for submissions of his work, he explained, "I hardly need to stress that what I write is always a very personal attempt to express intimate matters in modern form, and thus is unlikely to enjoy any 
appreciable degree of success as a book. I do not write much and when $I$ do it is only as a consequence of highly personal necessity."?

To discuss the problem of the individual who feels himself isolated from society, I have chosen to analyze Tonio Kroger, one of Thomas Mann's own attempts to reconcile the dichotomies in his own existence. It is an appropriate opening, for Mann makes clear the necessity for "artistic isolation," the "withdrawal from a living life," the introspection that is necessary for artistic creativity. Nevertheless, Mann is also attempting to make a personal statement. For some, he says, "das Talent war ein geselliger Schmuck." For others, however, "es gibt ein Kunstlertum, so tief, so von Anbeginn und Schicksals wegen," that the introspective, artistic talents have forced their way into the personal life of the Kunstler as well, and the result is a Kunstler who is "different," an individual who is isolated from the rest of mankind, not only as a Kunstler, but also as a human being.

Mann asserts not only that the Kunstler is by nature an individual "isolated" from the non-introspective sector of society, but also that this introspective talent can serve to isolate him from society as a.whole. The first thesis is the more easily examined and explained. It is a generality, explaining how the Kunstler creates. The second

7 Hermann Hesse, quoted in Bernhard Zeller, Portrait of Hesse, trans. Mark Hollebone (New York: Herder \& Herder, 1971), p. 108 . 
point goes deeper--it is Mann's personal statement. He is attempting to give form to his belief that he was "different" from other people, that his "otherness" was not due solely to his being a Künstler.

In order to analyze Mann's expression of the isolation of the individual, I have drawn heavily from the works of Hermann Hesse. Hesse, as we have seen, attempted to make personal statements about his feelings of intense personal isolation. By using his writings in conjunction with the works of Thomas Mann, it should be easier to demonstrate the feeling of isolation--not only the artistic isolation of the Künstler, but also the personal isolation of the individual.

"The true artist," we read in J.M. Neider's dissertation on. Thomas Mann, "is doubter and dreamer, an experimenter in the realm of feelings and ideas." 8 The artist, according to Mann, is by nature a doubter. For those, then, who have reached the stage of self-doubt on their search for a valid world-view, it is possible that Thomas Mann can offer reassurance that doubting and dreaming are necessary parts of the process of self-realization, of humanization.

The main consideration of this present work, then will be an examination of Tonio Kröger, one of Mann's own attempts to reconcile the dichotomies in his own existence. He had written in his short story "Tristan" (1902) that "es

8 Joan Merrick Neider, "Thomas Mann's Artistic Theory, 1900-1925," DAI, 32 (1971), 447A (Columbia University). 
geschieht nicht selten, daß ein Geschlecht mit praktischen, bürgerlichen und trockenen Traditionen sich gegen das Ende seiner Tage noch einmal durch die Kunst verklärt."9 I have therefore chosen as a theme Mann's fictionalized autobiographical account of himself as a young man caught in selfdoubt and discouragement, the Novelle written in 1903, Tonio Kröger. This work "tells the story of the tragic isolation of the poet who represents life but is excluded from life, whose sentence it is 'das Menschliche darzustellen ohne am Menschlichen teil zu haben,' who is condemned to know and to produce but not allowed to live. . ." 10 We will see that this is a triumphant story; it illustrates well that the stage of self-doubt and world-disillusionment can be overcome.

There are those, of course, who never reach this point. They are those who never examine "reality," who never feel, as Hermann Hesse terms it, "eine Wut auf dies abgetönte, flache, normierte und sterilisierte Leben und . . diesen gepflegten Optimismus des Bürgers; diese fette gedeihliche Zucht des Mittelmäßig̈en, Normalen, Durchschnittlichen."II But those who do reach this stage have begun the journey that Hesse terms the "Weg nach. Innen," which Mileck calls the "tortuous road that he hoped would lead to self-know-

9 Mann, G.W., VIII, p. 234.

10 Arthur Burkhard, "Thomas Mann's Treatment of the Marked Mann," PMLA, 43 (1928), 562.

11 Hesse, G.S., IV, p. 209. 
ledge and ultimately to greater self-realization."12

Hesse outlines the stages of Man's humanization in his essay "Ein Stückchen Theologie" (1932):

Der Weg der Menschwerdung beginnt mit der Unschuld (Paradies, Kindheit, verantwortungsloses Vorstadium). Von da führt er in die Schuld, in das Wissen um Gut und Böse, in die Forderungen der Kultur, der Moral, der Religionen, der Menschheitsideale. Bei jedem, der diese stufe ernstlich und als differenziertes Individuum durchlebt, endet sie unweigerlich mit Verzweiflung, nämlich mit der Einsicht, daß es ein Verwirklichen der Tugend, ein völliges Gehorchen, ein sattsames Dienen nicht gibt, daß Gerechtigkeit unerreichbar, daß Gutsein unerfüllbar ist. Diese Verzweiflung führt nun entweder zum Untergang oder aber zu einem dritten Reich des Geistes, zum Erleben eines Zustandes jenseits von Moral und Gesetz, ein Vordringen zu Gnade und Erlöstsein, zu einer neuen, höheren Art von Verantwortungslosigkeit, oder kurz gesagt: zum Glauben.13

When one has reached the level of despair, the path necessitates a re-examination of one's life and goals. For some, the re-examination reaffirms the validity of their lives, even though the life is at times terribly lonely. For others, the path is yet longer. Some look for and find solace in the morality as typified in Konrad von würzburg's poem "Der Welt Lohn": he who would save his soul must discard the world. This poor, disappointed person with the sensitive soul understands: preservation of the soul requires the abandonment of life. For the artist, as we shall see, this is a way out. His soul lies within his creations, and his creative ability depends upon his talent for looking

12. Joseph Mileck, Hermann Hesse: Life and Art (Berkeley: University of California Press, 1978), p. 67 .

13 Hesse, G.S., VII, p. 389. 
at life objectively. He can become a spectator of life, not a participant. He can "withdraw from life" in order to create, and in creating, his life is lived with satisfaction. Hermine, in Hesse's Steppenwolf, says, "Der Kampf gegen den Tod, lieber Harry, ist immer eine schöne, edle, wunderbare und ehrwürdige Sache, also auch der Kampf gegen den Krieg. Aber er ișt auch immer eine hoffnungslose Donquichotterie."14 But what of those who lose in the struggle, what of those who cannot find the beauty? Those, like Hesse's Steppenwolf, "are paralyzed by the conflict between the desire, to stay put and the desire to risk psychic or physical death for a relevant life that they can find nowhere in the 'normal' society." 15 These are those who cannot accept the solution of "dying to life in order to exist." These are the ones Casebeer describes as "those artistic, spiritual, scientific, or political intellectuals who have an intuition of the Immortal (Siddharthian) consciousness. Yet they are the sons and daughters of the middle class and are so trapped by its fears that they believe that to destroy their inherited conceptions of self would be suicide." 16

Goethe writes:

14 Hesse, G.S., IV, p. 308.

15 Edwin F. Casebeer, Hermann Hesse (New York: Thomas Crowell, 1972), p. 63.

16 Casebeer, p. 63. 
Der Selbstmord ist ein Ereignis der menschlichen Natur, welches, mag auch darüber schon so viel gesprochen und gehandelt sein als da will, doch einen jeden Menschen zur Teilnahme fordert, in jeder Zeitepoche wieder einmal verhandelt werden muß. Montesquieu . . . sagt, es müsse doch einem jeden freistehen, den fünften Akt seiner Tragödie da zu schließen, wo es ihm beliebe. Hier aber ist von solchen Personen nicht die Rede, die ein bedeutendes Leben tätig geführt, für irgend ein großes Reich oder für die Sache der Freiheit ihre Tage verwendet, und denen man wohl nicht ver"argen wird, wenn sie die Idee, die sie beseelt, sobald dieselbe von der Erde verschwindet, auch noch jenseits $z u$ verfolgen denken. Wir haben es hier mit solchen zu tun, denen eigentlich aus Mangel von Taten in dem friedlichsten $\mathrm{Zu}-$ stande von der Welt, durch übertriebene Forderungen an sich selbst das Leben verleidet.1?

We speak thus not of heroes. We speak of those whose single fault is this: they cannot find their places in this black/white sun. We speak of those who are often classified as "artists," if only to make their identification more easily understandable to the common man. We speak of those with the sensitive souls, the isolated individuals.

Neither the relationship of the artist to society nor the difficulties of adjusting to life (i.e., the suicide) are uncommon motifs in German literature. To be aware of how often this theme is used as a literary device, one need mention only a few of the many works on the subject: Goethe's Faust and Werther, Grillparzer's Sappho and Der arme Spielmann, Sudermann's Frau Sorge, Emil Strauss's Freund Hein, Hesse's Roßhalde and Der Steppenwolf, and Thomas Mann's Der Dilettant and Tod in Venedig. Moreover, we must be reminded, the sources of these types of works are 17 Goethe, Goethes Werk, IX, p. 583. 
not only literary, but most of.ten come from the lives of the authors themselves. John Kelly reminds us that in many of these works, "The central theme is the malheur d'être poète, the conflict between art and life. It is variously reflected in the Iives not only of Goethe, Grillparzer and Mann, but of Hoffman, Heine, Lenau, Byron, Poe and many another. Ibsen, for instance, complained of the ever increasing loneIiness into which he had worked his way."18 The tension is caused by the poet's desire to live and his need to create at the same time. It is this duality in his nature that forces him upon the path of humanization. The inevitable result is introspection, self-awareness, even when the outcome is still in doubt. Hense comes Grillparzer's lament: "In mir nämlich leben zwei völlig abgesonderte Wesen. Ein Dichter von der übergreifendsten, ja sich überstürzenden Phantasie und ein Verstandesmensch der kältesten und zähesten Art."19 Again, we see Faust's "two souls in my breast" repeated in Goethe's reflection on his own condition:

Vom Vater hab ich die Statur, Des Lebens ernstes Führen, Von Miutterchen die Frohnatur Und Lust zu fabulieren.

18 John Alexander Kelly, ed., Tonio Kröger: Novelle von Thomas Mann (New York: Appleton-Century-Crofts, 1959), p. ix.

1.9 Franz Grillparzer, "Selbstbiographie," in his Sämtliche Werke, ed. A. Sauer and R. Backmann (Vienna, 190948), Section I, vol. 16, p. 135, as quoted by W.E. Yates in his Grillparzer: A Critical Introduction (Cambridge: University Press, 1972 ), p. 83. 
Into their works, then, these authors have placed a bit of themselves, and the perceptive reader recognizes, even if at one step removed from reality, the soul of a Searcher, one who is aspiring to follow fully the path to humanization. This is the common thread that seems to run through the literary works, a thread captured by Gertrude E. Teller as she wrote on the works of another author of this genre, Stefan Zweig. She writes, "Zweig seems to say: the times may be Biblical or historical, the scene the East or the West, the same fundamental struggle between spirit and matter, love and hatred, ethics and force, can be detected everywhere and at all times. For this struggle is timeless and ageless; it. is in fact as old as conscious and civilized man." 20 The theme, then, is one of unitary existence in a dual world; the necessity is to fuse the two poles before the tension between them leads to destruction.

Hesse calls this the search for the Kingdom of the Spirit. Elsewhere it is described as the "myth of the quest. . . The theme is so pervasive, in fact, that some scholars have argued that it determines virtually all mythic and literary patterns."2l Theodore Ziolkowski tells us that the instinctive response of the German consciousness to the cue-word "Quest" is almost totally predictable--it is Parzival and the Holy Grail. In his

20 Gertrude E. Teller, "Virata or The Eyes of the Undying Brother and Stefan Zwe ig's. Thought, " Germanic Review, 27 (1952), 36.

21 Theodore Ziolkowski, "The Quest for the Grail in Hesse's Demian," Germanic Review, 49 (1974), 46. 
1939 "Introduction to The Magic Mountain," for instance, Thoma.s Mann made no secret of his pleasure at learning from a young scholar-critic (Howard Nemerov) that his novel, published some fifteen years earlier, had all the hallmarks of the venerable tradition of the Quester Myth. Aware that this myth is to be found in the writings of all peoples, Mann cites Faust as the most famous manifestation of the myth created in Germany. "Aber hinter Faust, dem ewigen Sucher," he continues, "steht die Gruppe von Dichtungen, die den allgemeinen Namen von Sangraal oder Holy Grail romances tragen." And it is this Grail Quester, specifically Parzival, the "guileless fool," who is taken to prefigure Hans Castorp, the hero of Der Zauberberg. A brief consideration of Goethe's Wilhelm Meister leads Mann to the sweeping conclusion that the entire tradition of the German Bildungsroman can be regarded as a "Sublimierung und Vergeistigung" of those romances in. which the legend of the Grail was originally embodied. 2

Ziolkowski notes that over the years, the myth has become internalized, and the action takes place no longer in the real world, but rather in the consciousness of the hero. The goal is no longer a tangible goal, a "Grail," but is instead the self-awareness of the hero. This shift in consciousness is indicated, for example, by Hesse in his Prologue to Demian, where the narrator states, "Ich war ein Suchender und bin es noch, aber ich suche nicht mehr auf den Sternen und in den Büchern, ich beginne die Lehren $\mathrm{zu}$ hören, die mein Blut in mir rauscht." 23

The way to salvation, then, is a "Weg nach Innen," a fusing of the two extremes, a raising to a higher level of consciousness, a process of humanization. Those who undergo this process begin by feeling themselves to be "different"

Ziolkowski, pp. 46-47.

23 Hermann Hesse, G.S., III, p. 102. 
from others. They feel themselves cut off from the normal world and too often feel that they themselves are at fault, that there is something wrong with their own souls. This is the germ that can lead to suicide, for death is a strong alternative to the feeling that one is not capable of living on this earth without sacrificing the soul.

Hesse, speaking of the Steppenwolf, writes that "er gehörte zu den Selbstmördern. Hier muß̉ gesagt werden, daß es falsch ist, wenn man nur jene Menschen Selbstmörder nennt, welche sich wirklich umbringen. . . Unter den Menschen . . welche dem Wesen nach zu den Selbstmördern zählen, sehr viele, vielleicht die meisten, miemals tatsächlich Hand an sich legen. . . Aber dem Selbstmörder ist es eigentümlich, daß er sein Ich, einerlei, ob mit Recht oder Unrecht, als einen besonders gefährlichen, zweifelhaften und gefährdeten Keim der Natur empfindet. . . . "24

As Hesse. states, the "suicides" often "never in fact lay hands on themselves." They are marked, rather, by a certain introspection, a certain self-awareness, a certain self-castigation which places them at odds with the world. The difficult motif, then, is neither actual suicide nor the relationship of the ordinary Künstler to society, but is rather the relationship of the "suicide" to society. The Bürger and the ordinary Künstler are both members of a black/white world; the "suicide" is not. 
The "suicides" have long suffered under the Faustian dictum: "Zwei Seelen wohnen, ach: in meiner Brust." We shall see that this view must be changed. The "two souls" must be reconciled. If we recognize the true position of the "suicide," we must understand that the world is not a bipolar thing, a simple black/white problem. G.W. Field points out two obvious ittems: "(a) true polarities are opposites held in dynamic, productive tension or opposites which are bridged or unified in a higher synthesis; (b) the polarities are usually themselves part of an evolving process."25 We will, as G.S. Métraux mentions, "have to replace the uni-dimensional conception of man by a multidimensional notion of the human being." 26

If the "suicide" succeeds in this attempt at selfawareness, he will at last understand that it is not his task to reconcile his differences by "killing" part or all of himself in order to live. He instead realizes the power and inevitability of his fate and the extreme honor and responsibility he has been granted by being endowed as he has been. In Thomas Mann's "Schwere Stunde," we see in his portrayal of Schiller that poet's powerful acknowledgement of his fate: "Denn tiefer noch als diese Ichsucht lebte das Bewußtsein, sich dennoch bei alldem im Dienste vor irgend

25 G.W. Field, "Hermann Hesse: Polarities and Symbols of Synthesis," Queen's Quarterly, 81 (1974), 88-89.

26 G.S. Métraux, "The Psychic Evolution of Modern Man: Steppenwolf by Hermann Hesse (1927)," trans. Aline B. Werth, Cultures, 4, No. 4 (1977), 42 . 
etwas Hohem, ohne Verdienst freilich, sondern unter einer. Notwendigkeit, uneigennützig zu verzehren und aufzuopfern. "27 The Searcher no longer looks for the release of death. It is rather his new task to search for a "rebirth" into the living and "to find a means of living with inner contradictions, and even using them as a reason for existence and action." 28

The nature of the Künstler requires him to live apart from the "normal" world. He acknowledges that he cannot live a "normal" life, and yet when he applies his introspective artistic habits to his non-artistic existence, he is most in danger of developing "suicidal" tendencies. Within Thomas Mann's work Tonio Kröger, Tonio describes a fellow Künstler, an actor, thus: "Ich kannte einen Schauspieler von Genie, der als Mensch mit einer krankhaften Befangenheit und Haltlosigkeit zu kämpfen hatte. Sein überreiztes Ichgefühl zusammen mit dem Mangel an Rolle, an darstellerischer Aufgabe, bewirkten das bei diesem vollkommenen Künstler und verarmten Menschen. . . "29 The theme is familiar; the actor numbers among the "suicides."

To examine this problem of the seeming duality of the world and the "suicidal" tendencies of those who cannot adapt to it, I have therefore chosen as my theme the Novelle

\author{
27 Mann, G.W., VIII, pp. 376-77. \\ 28 Métraux, p. 44. \\ 29 Mann, G.W., VIII, p. 297.
}


of Thomas Mann, Tonio Kröger. Here we see Tonio Kröger, striving to live a satisfying life, yet obliged to sorrow because of his separation from both the world of the Buirger and the world of the Künstler. Under examination, Tonio Kröger will. show us that there is such a thing as artistic isolation. The poignancy of this work, however, is drawn from the sufferings of Tonio, for he is "ein Künstler, ein wirklicher, nicht einer, dessen bürgerlicher Beruf die Kunst ist, sondern einer vorbestimmte und verdammte. . ."30 we will see that not only in the world of the Bürger, but also among the Künstler with their artistic isolation, there still can exist that misunderstood creature, the isolated individual.

The world is not black/white. There is another world, a third world. This is the world of the Tonio Krögers. These people, "suicides" who suffer because of their sensitive souls, their habits of introspection involving all phases of their lives, are tormented by their inability to be normal members of a normal world. They suffer until they realize that the world need not be black/white, that their own position in the world is valid, that they are not singular oddities.

There is a barrier--an invisible, one-way barrier-between the alienated man, the isolated individual, and the outside world. The isolated man alone is capable of por- 
traying either position, for he alone has seen both worlds. The normal man by his very nature will never understand the isolated man's position or condition, for he has never been there. The difficulty of trying to portray the loneliness of the isolated individual to the Bürger, the man who has never felt this separation, was voiced by Hermann Hesse during a period when he was attempting to come to grips with his own life. In his essay "Kurzgefaßter Lebenslauf," Hesse states:

Ich . . hatte erst die Achtung vor mir selbst, dann die Verachtung meiner selbst zu verlieren, hatte nichts andres zu tun, als den Blick ins Chaos zu Ende zu tun, mit der oft aufglühenden, oft erlöschenden Hoffnung, jenseits des Chaos wieder Natur, wieder Unschuld $\mathrm{zu}$ finden. Jeder wach gewordene und wirklich zum Bewußtsein gekommene Mensch geht ja einmal, oder mehrmals diesen schmalen Weg durch die wïste--den andern davon reden $\mathrm{zu}$ wollen, wäre vergebliche Mühe. ${ }^{1}$.

This was the difficulty faced by Thomas Mann as he wrote Tonio Kröger, for he was forced to realize that many would see in this work "a tender study of youth." 32 and an attempt "to visualize a reconciliation between art and Iife," 33 but nothing more. As Nietzsche wrote in Ecce Homo:

31. Hermann Hesse, "Kurzgefaßter Lebenslauf," in Materialien zu Hermann Hesses "Der Steppenwolf», ed. Volker Michels (Frankfurt/M.: Suhrkamp, 1972), pp.18-19.

32 E.M. Wilkinson, "Tonio Kröger: An Interpretation," in Tonio Kröger, ed. E.M. Wilkinson (Basil Blackwell, 1944), rpt. with slight modifications in Thomas Mann: A Collection of Critical Essays (Englewood Cliffs, N.J.: Prentice-Hall, $1964)$, p. 22 .

33 W.H. Rey, "Tragic Aspects of the Artist in Thomas Mann.'s Work," Modern Language Quarterly, 19 (1958), 197. 
"Zuletzt kann niemand aus den Dingen, die Bücher eingerechnet, mehr heraushören, als er bereits weiß. Wofür man vom Erlebnisse her keinen Zugang hat, dafür hat man kein ohr." 34

Hesse acknowledged this difficulty, and incorporated into the very structure of Steppenwolf the message that the work was "nicht für jedermann" and furthermore "Nur für. Verrückte!" We see in his essay "Geçanken zu Dostejewskis «Idiot»" (1919) that "die "Verrückten» sind jene seltenen Einzelgänger . . die die ganze Relativität von Gut und Böse erkannt haben; sie sịnd zwar Bewohner dieser Welt, haben aber gelernt, daș Leben aus dem Blickfeld der Unsterblichen zu betrachten. . . Sie denken «magisch», weil sie über die scheinbare «Wirklichkeit» der bürgerlichen Welt der Erscheinungen hinaussehen in die eigentliche Wirklichkeit der kosmischen Harmonie." 35

To be understood, to be befriended by one who understands, brings an imcomparable sense of relief and reward to a Seeker on the "Weg nach Innen." Imagine the hope that comes to the Steppenwolf when Hermine tells him, "Aber verstehen, Freund, so wie ich dich verstehe, wird Maria dich nie und keine andere."36 And yet loneliness also comes with

34 Friedrich Nietzsche, Werke in drei Bänden, ed. Karl Schlechta (Mürchen: Carl Hansen Verlag, 1960), II, 1100.

35. Theodore Ziolkowski, "Hermann Hesses «Steppenwolf»: Eine Sonata in Prosa," in Materialien zu Hermann Hesses "Der Steppenwolf», ed. Volker. Michels, p. 368. 36. Hesse, G.S., IV, p. 338. 
this affirmation that there are so few who do understand. Mann has indicated that Tonio is not to find this companionship yet, but that Tonio will become aware of the validity of his life. We see this not through overt warnings, but through subtle signs. The king in Don Carlos weeps, and Tonio, too, weeps with the king, but Hans Hansen cannot sympathize, for "this power to weep with the king implies knowledge of a kind that Hans will never have, 'star pupil' though he be. For it is not the result of gifts or ability, but of an inner relation to events." 37 And Tonio's singularity in the world of this Novelle is indicated after his blunder in the dance at Ingeborg Holm's house. At that point, Kenneth Wilson writes, "Tonio retịres to the shuttered window, a kind of mirror, an opening through which only he with his special perceptivity can see, there to observe himself and the dancers and to realize that he must always be apart." 38

Arthur Burkhard writes that Tonio Kröger exemplifies "what Thomas Mann feels to be the irreconcilable conflict between Bürger and Künstler."39 other critics have concluded that the work "can be said to have no tangible con-

37 wilkinson, pp. 22-23.

38 Kenneth G.Wilson, "The Dance as Symbol and Leitmotiv in Thomas Mann's Tonio Kröger," Germanic Review, 29 $(1954), 284$.

39 Burkhard, p. 562 . 
clusion." 40 . But we have seen that in the modern myth, the "Grail" is no longer a tangible item, but a gaining of selfawareness. In this sense, Tonio Kröger succeeds; the Novelle, written by a man who is himself an isolated individual, a man with a "mark on his brow," concludes with Tonio's obtaining his philosophical "Grail."

I will be presenting Tonio Kröger from this viewpoint: Tonio as an outsider to the "normal" world, a position which goes beyond mere artistic isolation. Moreover, Tonio's problem goes beyond what is termed "the despair of the modern intellectual," for the intellectual has consciously shunned the compromises which the Bürger makes to avoid the extremes. Tonio has shunned the compromises not out of choice, but out of uncertainty. For him the question is not, "What is the world coming to?" but rather, "Why am I unwilling to sacrifice my morality, why am I unable to live a happy, normal Iife?"

The conclusion is not tragic nor intangible; the work ends on a note of hope and a renewal of life. The secret lies in the gained awareness of the hero that his problems are solvable in this world, that his uniqueness is a gift, not a curse, and that his way of thinking is not and never was "wrong." Tonio knows it and writes, "Ich werde Besseres machen, Lisaweta. . . Ich schaue in eine ungeborene und schemenhafte WeIt hinein, die geerdnet und gebildet sein

40 Lida Kirchberger, "Popularity as a Technique: Notes on Tonio Kröger," Monatshefte, 63 (1971), 324. 
will, ich sehe in ein Gewimmel von Schatten memschlicher Gestalten, die mir winken, daß ich sie banne und erlöse: tragische und lächerliche und solche, die beides zugleich sind,--und diesen bin ich sehr zugetan." 41

$4 I$ Mann, G.W., VIII, p. 338. 
THOMAS MANN AND TONIO KRÖGER

Henrik Ibsen once summed up his philosophy:

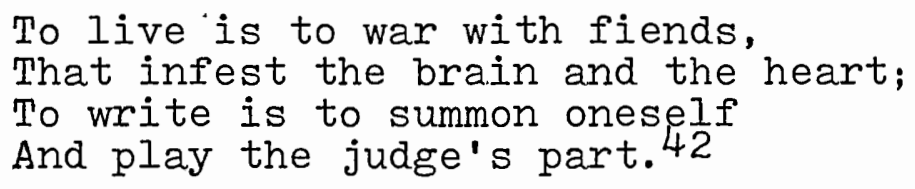

Goethe, in his Gespräche mit Eckermann (20 April

1825), states: "Im übrigen aber ist es zuletzt die größte Kunst, sich zu beschränken und $\mathrm{zu}$ isolieren." 43 Nowhere are these two philosophies more evident than in the works termed Künstlerroman and Bildungsroman. In the latter, the author makes judgements on the development of a character. In the former, the author concentrates on the relationship of the character to society. In such works, the authors have turned to subjects they know best: the problems that beset the Kunstler. In each of these, as we would expect, is a bit of concealed autobiography. What we see and feel is what the author himself has seen and felt, even if hidden under an artistic layer.

42 Henrik Ibsen, as quoted in Zucker, Ibsen, p. 189, from Mary Morison, ed., The Correspondence of Henrik Ibsen (London: Hodder and Stoughton, 1905), No. 148, identical with Letters of Henrik Ibsen, trans. John Nilsen Laurvik and Mary Morison (New York: Duffield and Co., 1908).

43 Johann Wolfgang von Goethe, Eckermann: Gespräche mit Goethe, ed. Hans Timotheus Kroeber (Weimar: Gustav Kiepenheuer Verlag, 1918), p. 131. 
Hermann Hesse has described this process in his 1928 essay "Eine Arbeitsnacht." He states:

Eine neue Dichtung beginnt für mich in dem Augenblick zu entstehen, we eine Figur mir sichtbar wird, welche für eine Weile Symbol und Träger meines Erlebens, meiner Gedanken, meiner Probleme werden kann. Die Erscheinung dieser mythischen Person (Peter Camenzind, Knulp, Demian, Siddhartha, Harry Haller, usw.) ist der schöpferische Augenblick, aus dem alles entsteht. Beinahe alle Prosadichtungen, die ich geschrieben habe, sind Seelenbiographien, in allen handelt es sich nicht um Geschichten, Verwicklungen und Spannungen, sondern sie sind im Grunde Monologe, in denen eine einzige Person, eben jene mythische Figur, in ihren Beziehungen zur Welt und zum eigenen Ich betrachtet wird.

Thus we see that the creative process in many works is a self-confession, drawn from the life experiences of the author. Thomas Mann was such an author, and he once stated that all of his stories "are autobiography in the guise of fables." 45 One such work is Tonio Kröger; Bürgin and Mayer indicate that Mann had been prodded by "life" into writing this artistic autobiography:

September, 1899

Urlaubsreise nach Dänemark. Besuch Lübecks, Logis im Hotel «Stadt Hamburg»; Episode der beinahe erfolgten Verhaftung wegen Hochstapelei in der Vaterstadt, neuntätiger Aufenthalt in Aalsgaard am Sund. Konzeptien der Novelle «Tonio Kröger».46

Other critics provide confirmation of Thomas Mann's intents. William V. Glebe states it in this manner:

44 Hesse, G.S., VII, p. 303.

45 Thomas. Mann, as quoted in Joseph Warner Angell, ed., The Thomas Mann Reader (New York: Knopf, 1950), p. 5. 46 Hans Bürgin and Hans-otto Mayer, Thomas Mann: Eine Chronik seines Leben (Frankfurt/M. : S. Fischer Verlag, 1965), p. 19. 
Thomas Mann, aware early in life of his artistic leanings, came to look upon himself as an oddity. He brooded upon what he considered his fate as a bourgeois who had gone astray in art. His awareness of his isolation from the normal world caused him much suffering and agony. In such a state he turned the more ardently to his art, using it as a means of striking out at a world which, as he felt, had cut him out of its existence because of what he was. 4 ?

When one considers, however, that Thomas Mann's "autobiographical fables" were steps on his own path along that "Weg nach Innen," one sees somewhat more than art as a "means of striking out at a world.". Thomas Mann clearly uses his art in the manner of the literary man: as a means of dispassionately examining his own feelings, coming to some sort of a conclusion, and then "expressing" them. Through the course of his literary career, he examined various points of his own existence, and the resulting works can all be seen as monographs describing one thing, the isolated individual. Because he himself was a literary man, Mann often used writers as the Kunstler model for his works. Still, it can be shown that Mann's expression of the isolation of the Künstler was something more than mere artistic isolation.

William Glebe, writing on Mann's "Little Herr Friedemann," comments that it is "one of the first of his tales to appear in print . . . setting the tone for all his subsequent stories. It . . introduces the important themes

47 William V. Glebe, "The Artist's 'Disease' in Some of Thomas Mann's Earliest Tales," Books Abroad, 39 (1965), 261 . 
of 'disease' and suffering of the artist-type of character together with the motif of art and artist versus life." 48 Mann was to delve deeper into the sources of this suffering. Arthur Burkhard states:

Moreover, the problem of Tonio Kröger and Thomas Mann, of the artist descended from burghers, who feels the "philosophische Vereinsamung" of his "Ausserhalbstellung" is the problem of most of Mann's early work; of Tonio Kröger, of Tristan, of Tod in Venedig, of Buddenbrooks.

The same type of artist, descended from respectable bourgeois stock, but feeling himself an outsider and left to cope with life alone, we shall meet again in Axel Martini, the poet in Mann's novel, Königliche Hoheit; in Savonarola, the preacher in Mann's drama, Fiorenza. The same "Entbürgerlichung," the same descent from sound Bürgertum to unsound Künstlertum, forms the background for Mann's first long, and still perhaps best-known work, Buddenbrooks, with its characteristically ominous sub-title, "Verfall einer Familie:"49

Another of the early works that dealt with the problem of isolation was the story "Der Dilettant." Of this, Glebe states:

That the tale is heavily autobiographical is evidenced by the details of Mann's early life as these are known to us today... . . The Dilettante is the first of Thomas Mann's artist-types to be struck down by the artist's "disease.". . . No sooner has he set up his quarters than he senses a vague fear that something is not quite in order about his decision to devote his life to quiet contemplation and the pursuit of selfish pleasure in isolation. It is the same guilt which Thomas Mann felt early in life, it is the beginning of a case of "bad conscience." The Dilettante is to find himself trapped in a vacuum between two worlds, torn by the desire to belong to both at the same time. The more he ponders his philosophical isolation, the more he questions whether he had done right to shut himself

48 Glebe, p. 261.
49 Burkhard, p. 563. 
off from "people," to deny the honorable pursuits of his fellow burghers." 50

The theme, then, is one of philosophical isolation as much as artistic isolation. It was often examined by Mann as a means of expressing his own inner convictions. His models may have been borrowed from his observations, but the heroes of his tales espouse Mann's own convictions. His son, Golo Mann, tells us, "He was no Naturalist. His way was to watch for a short time, discreetly, at a distance, and to look out from within." 51 And if Mann was attempting to express his own problems and feelings, after Buddenbrooks, what type of framework would be sufficient to form his thoughts? Reed asks, "What experience was to hand as grist for the literary mill? Only the experience of being cut off from normal experience." 52 Mann came to realize that the Künstler was destined to be an observer of, and not a participant in, "normal" life, and this was one sense, Reed states, in which he understood Nietzsche's comment: "Ein vollkommener und ganzer Künstler ist in alle Ewigkeit von dem «Realen», dem Wirklichen abgetrennt. . . . 53

Golo Mann writes that his father "so often, if he did

50 Glebe, pp. 266-67.

51 Golo Mann, Thomas Mann, 1875/1965; Memories of My Father (Bonn: Inter Nationes, 1965), p. 5 .

52 T.J. Reed, Thomas Mann: The Uses of Tradition (Oxford: The Clarendon Press, 1974), p. 91 .

53 Nietzsche, Zur Genealogie der Moral, in Werke in drei Bänden, II, 843. 
not exactly give a portrait of himself, made confessions in his writings and gave his characters a part of himself. His clearest self-portrait as a youth is Tonio Kröger. . . . 54 Mann himself writes in his Betrachtungen eines Unpolitischen (1918): "Wo ist er jetzt, der Göttinger Student von damals, mit dem mager-nervösen Gesicht, der mir . . mit seiner hellen, bewegten stimme sagte: 'Sie wișen es hoffentlich, nicht wahr, Sie wissen es,--nicht die «Buddenbrooks» sind Ihr Eigentliches, Ihr Eigentliches ist der "Tonio Kröger»!" Ich sagte, ich wüßte es."55. And John Kelly says that "in 1930 he wrote in his Lebensabriß that of all his works Tonio Kröger, the favorite among them of young people, still stood closest to his heart. The reason for this is apparent enough; it came from his heart and is the most specifically autobiographical of all the works of this poet who like Goethe reveals himself on every page he writes. " 56

We shall examine Tonio Kröger, and our theme, then, is clearly to be somewhat beyond the artistic isolation necessarily endured by the Künstler. For this Novelle, Mann drew not only upon his experience and life, but also upon his education. Iida Kirchberger writes that "Goethe must be placed first among poets on whom Thomas Mann relied

54 Golo Mann, p. 14.

55 Thomas Mann, G.W., XII, pp. 90-9I. 56 Kelly, p. viii. 
both consciously and unconsciously for the composition of Tonio Kröger. " 57 She goes on to compare Tonio Kröger with Goethe's Die Lieiden des jungen Werther and Storm's Immensee. She mentions, "In both Werther and Immensee the plot concerns a man of contemplation and artistic predilection who loses in love to a practical man of action. . . ."58 Tonio matches this pattern, in that he loses Hans Hansen to the more practical Irwin Immerthal, and Ingeborg Holm to the dancing master, Herr Knaak. Even Lisaveta' Ivanovna's understanding is reserved for the novelist Adalbert, the man who knew what he wanted. Tonio's problems are the problems of a man of contemplation in a world of men of action. Mann's hero is a Künstler, and thus we recognize the theme in Tonio Kröger, the story of "an artist unhappy and yet at the same time envious in a bourgeois and realistic world of normal and healthy men and women. . . . 59

Mann is indeed indebted to these sources for his story, and by this we see that perhaps there is more to this tale than mere "problems of how an artist creates." Reed states, "The technique of weaving in quotation and allusion to famous texts was one Mann had practiced skilfully before, not merely to decorate his fiction, but to add a dimension of

57 Kirchberger, pp. 323-24.

58 Kirchberger, p. 324.

59 Werner P. Friederich, An Outline History of German Literature, 2nd ed. (1961; rpt. New York: Barnes \& Noble, 1970), p. 220 . 
meaning to what was being narrated." 60 This technique is illustrated by the importance of Tonio's concern--and Hans's unconcern--with Schiller's Don Carlos. E.M. Wilkinson points out that reading Schiller becomes an aesthetic experience for Tonio. Two further examples are occasioned by Tonio's withdrawals twice from the scene of a dance, a group activity performed by "normal" people. Tonio quotes from Immensee, enhancing his separation from the "practical men of action." And from Mann himself we read of his connection to the work of Goethe. In a letter written to Agnes E. Meyer in 1941, Mann states: "Schließlich ist es mein «Werther»-wenn auch unwahrscheinlich ist, daß Napoleon den T.K. siében mal gelesen hätte."6I

60 Reed, p. 156.

61 Thomas Mann, letter to Mrs. Agnes Meyer, 26 July, 1941, in Briefe, 1937-1947, ed. Erika Mann (n.p.: S. Fischer Verlag, 1963), p. 202 . 


\section{CHAPTER III}

\section{THE WORLD OF TONIO KRÖGER}

The world of Tonio Kröger is a world of Bürger and of Künstler, a world of respectable merchants and of people likened to "gypsies in green wagons." Within this structured world appears a figure, moved by the values affecting both sectors of society, and yet belonging to neither. What happens when an individual in unable to fit into any given sector of society? He becomes isolated and suffers doubt, torment and anguish. Tonio Kröger is such a story of the relationship between art and life. Tonio Kröger is Thomas Mann's portrayal of the necessary isolation of the Künstler and of the isolation of an individual, even within the artistic world itself.

$\because$ In a letter to his artist friend Iisaveta Ivanovna, Tonio Kröger describes himself in this manner: "Ich stehe zwischen zwei welten, bin in keiner daheim und habe es infolgedessen ein wenig schwer. Ihr Künstler nennt mich einen Bürger, und die Bürger sind versucht, mich zu verhaften . . . ich weiß nicht, was von beidem mich bitterer kränkt." 62 Tonio writes that he stands in both worlds, but is "in keiner daheim." We should rather expect that one who has 
made the transition from one world to the other would be "at home" in both. Making the transition from one world to the other implies having the capabilities of choosing which world one wishes to live in. As Henry Hatfield tells us, Tonio "has escaped from the world of his paternal tradition, but he is no more at home among the Bohemians of Munich than he had been among the burghers, and the latter he had at least respected." 63

The Künstler and the Burger would both like to believe the world contains only this two-fold dividion: Kunstler/Bürger. The Bürger looks upon the Künstler with scorn and derision and upon the artistic life as having little practical value. Tonio admits, "Sehen Sie, Lisaweta, ich hege auf dem Grunde meiner Seele--ins Geistige übertragen-gegen den. Typus des Künstlers den ganzen Verdacht, den jeder meiner ehrenfesten Vorfahren droben in der engen Stadt irgendeinem Gaukler und abenteuernden Artisten entgegengebracht hätte, der in sein Haus gekommen wäre."64 We see such sentiments of bürgerlich opinions stated even earlier in Mann's novel Buddenbrooks. Gerda, the wife of Thomas Buddenbrooks, tells her husband:

Thomas, ein für allemal, von der Musik als Kunst wirst du niemals etwas verstehen, und so intelligent du bist, wirst du niemals einsehen, daß sie mehr ist als ein kleiner Nachtischspaß und Ohrenschmaus. In der Musik geht dir der Sinn für das Banale $a b$,

63 Henry Hatfield, Thomas Mann, rev. ed. (New York: New Directions, 1962), p. 52 .

64 Mann, G.W., VIII, p. 298. 

der dir doch sonst nicht fehlt. . und er ist das
Kriterium des Verständnisses in der Kunst. 65

The Bürger is suspicious of and often misunderstands the life of the Kunstler. The Künstler, in turn, looks upon the Bürger with equal scorn and considers him equally incompetent to understand the complexities of the artistic life. Gerda, in voicing her husband's opinion of music, is also giving us her opinion as a Künstler of the Burger's understanding of Kunst. Tonio, too, voices his feelings when he considers the case of the Bürger who makes an attempt to entertain artistic practices. "Wir Künstler verachten niemand gründicher als den Dilettanten, den Lebendigen, der glaubt, obendrein bei Gelegenheit einmal ein Künstler sein zu können." 66

Still, there is yet a third type of individual, the isolated man, the man neither a complete Bürger nor a complete Künstler. Mann presents us with one: Tonio Kröger. The isolated individual in our bipolar world is often classified among the Künstler, for he, like the Künstler, is prone to introspection, which is necessary for creative work. Still, let us not confuse the Tonio Krögers with the Adalberts and the Lisaveta Ivanovnas. Isolation occurs most necessarily among the Künstler, but it does not follow that all Künstler are aware of the meaning of personal isolation. The life of a Künstler demands a different discipline $65 \operatorname{Mann}$, G.W., I, p. 509. 66 Mann, G.W., VIII, p. 304 
from the life of a Bürger. Tonio attempts to delineate this difference: "Es ist nötig, daß man irgend etwas Außermenschliches und Unmenschliches sei, daß man zum Menschlichen in einem seltsam fernen und unbeteiligten Verhältnis stehe. . . "67 But what confuses and misleads Tonio is his failure to recognize the artistic community as a humanity in itself. Instead his gaze merely sees without recognizing the humanity that resides among those Künstler whom he terms "jene Kleinen, denen das Talent ein geselliger Schmuck war, die, ob sie nun arm oder reich waren, wild und abgerissen einhergingen oder mit persönlichen Krawatten Luxus trieben. . . "68 Tonio Kröger recognizes that the very essence of being a Künstler requires that one isolate himself from humanity, but what he fails to recognize is that the artistic life can form a humanity of its own, and therefore he fails to recognize his own unique, isolated position in neither world, artistic nor bürgerlich. He alone in the story is in the position of Hamlet the Dane, that is, he has been called to knowledge, to the artistic life, without being born to it. This is the cause and basis of his isolation.

What is this "isolation" that is forced upon the Künstler? It is the artistic requirement that the Künstler "zum Menschlichen in einem seltsam fernen und unbeteiligten

67 Mann, G.W., VIII, pp. 295-96.

68 Mann, G.W., VIII, p. $29 I$. 
Verhältnis stehe." Just as man is part of the animal life upon this planet and yet is fundamentally distinct, in that man alone among the animals ponders about the relationship between himself and the other animals, so is the Künstler distinct from the Bürger, for only the Künstler's profession requires him to examine and classify his motives and emotions; to step back, so to speak, from participation in human life in order to examine cooly and dispassionately how life operates.

Thomas Mann himself has expounded upon this problem of the reflective-analytic artist, whom he termed a "Literat," in his 1913 essay "Der Künstler und der Literat." In commenting on this work, Horst Daemmrich states, "The basic temper of this artist (Literat) is analytic and introspective, a disposition which estranges him from naive art, indeed from the rest of society." 69 . We note here that Tonio Kröger is estranged not only from the Bürger, but also from the artistic world of Iisaveta Ivanovna, a sensuous-creative artist type which Mann terms "Künstler." The Iiterat "creates his own idealistic image of the world and fights against the corruption of his ideals by reality . . . Since his vision is always directed toward the ideal, he may manifest the desire to ennoble and improve man, but he is also clearly in danger of scorning those who do not mea-

69 Horst S. Daemmrich, "Mann's Portrait of the Artist: Archetypal Patterns," Bucknell Review, 14, No. 3 (1966), 29. 
sure up to his high standards."70 Indeed, this is a common danger, and such a feeling is illustrated by Hesse in his novel Unterm Rad:

Nur er allein war frei und entlassen. Er hatte sie überholt, sie standen jetzt unter ihm. Sie hatten ihn genug geplagt, weil er außer August keine Freundschaften und an ihren Raufereien und Spielen keine rechte Freude gehabt hatte. So, nun konnten sie ihm nachsehen, die Dackel, die Dickköpfe. Er verachtete sie so sehr, daß er einen Augenblick zu pfeifen aufhörte, um den Mund zu verziehen. 1

To a certain definite extent, then, the Künstler must be isolated from humanity. He must examine feelings in order that he may describe reality, but this withdrawal from humanity brings its own burdens. Daemmrich states, "But while all of these artists delight in their ability to gain distance, since it enables them to work with utmost precision, they are burdened by it as human beings. They suffer from the conflict between their artistic temperament and the human desire to experience 'simple, heartfelt' emotions."72 The danger is that when the Kunstler is captured by his own feelings, he becomes sentimental, and thus banal and futile. Tonio says, "Denn so ist es ja, Lisaweta: Das Gefühl, das warme, herzliche Gefühl ist immer banal und unbrauchbar. . . Es ist nötig, daß man etwas Außermenschliches und Unmenschliches sei. . . Die Begabung für Stil, Form und Ausdruck setzt bereits dies kühle und wählerische verhältnis zum

Daemmrich, p. 29.

71 Hesse, G.S., I, p. 406.

72 Daemmrich, p. 36. 
Menschlichen, ja, eine gewisse menschliche Verarmung und verödung voraus."73

Tonio explains, "Denn das gesunde und starke Gefühl, dabei bleibt es, hat keinen Geschmack."74 Natural feelings are not the main consideration of the Künstler. His primary consideration is rather the form of his expression of those coolly examined feelings. Tonio asserts, "Denn das, was man sagt, darf ja niemals die Hauptsache sein, sondern nur das an und für sich gleichgültige Material, aus dem das ästhetische Gebilde in spieldender und gelassener Überlegenheit zusammenzusetzen ist." 75

Thus the Künstler recognizes Schiller's dictum: "In einem wahrhaft schönen Kunstwerk soll der Inhalt nichts, die Form aber alles tun; denn durch die Form wird auf das Ganze des Menschen, durch den Inhalt hingegen nur auf einzelne Kräft gewirkt."76 Nevertheless, it is this realization of the necessity for a dispassionate, rather than a sentimental attitude toward the expression of feelings which isolates the Künstler from the masses. And such an attitude can only serve to increase his awareness of this isolation. As Christa Kamenetsky has pointed out, "What

73 Mann, G.W., VIII, pp. 295-96.

74 Mann, G.W., VIII, p. 296.

75 Mann, G.S., VIII, p. 295.

76 Friedrich Schiller, "Ästetische Erziehung: Zweiundzwanzigsten Brief," in Sämtliche Werke, 4 th ed. (n.d.; rpt. Niunchen: Carl Hansen Verlag, 1965), p. 639. 
troubles him most is that when he feels very intensively, he seems to be the least artistic in his expression, whereas when he reaches a certain degree of perfection in form, he knows all too well that he has said the least of what really does concern him." 77

Adalbert, Tonio's novelist friend, recognized this dilemma, and when his work became suffocated from an influx of sentimental feelings, he knew enough to withdraw from his work and to retire to his cafe. We might ask what happens when feelings are allowed to continue unchecked, when artistic efforts and talents are not employed to shape the raw material. Such attempts are performed by the naive, the undisciplined, that is to say, the Buirger. The true Künstler recognizes that the creative process is a struggle and he is suspicious of all undisciplined efforts. Mann voices this assertion in "Schwere Stunde":

Das Talent selbst--war es nicht Schmerz? . . Es hatte noch niemals gesprudelt, und sein Mißtrauen würde erst eigentlich beginnen, wenn es das täte. Nur bei stümpern und Dilettanten sprudelt es, bei den Schnellzufriedenen und Unwissenden, die nicht unter dem Druck und der Zucht des Talentes lebten. Denn das Talent, meine Damen und Herren dort unten, weithin im Parterre, das Talent ist nichts Leichtes, nichts Tändelndes, es ist nicht ohne weiteres ein Können. 78

In Tonio Kröger we are shown the inevitable results of a number of bürgerlich artistic efforts. One such effort

77 Christa Kamenetsky, "Dichter vs. Literat: Thomas Mann's Ironic Views of the Literary Man," College Language Association Journal, 14 (1971), 424.

78 Mann, G.W., VIII, pp. 375-76. 
takes place on the boat ride from Lübeck to Denmark. For a time, a young Hamburg merchant on his holiday stands apart with Tonio and watches the stars and the sea. This reddishblond young man is overcome by the majesty of the raw night elements and admits, "Ich bin fast immer wehmütig, aber besonders an solchen Abenden wie heute, wenn die Sderne am Himmel sdehn."

"Sicherlich schreibt er Verse, dachte Tonio Kröger, tief ehrlich empfundene Kaufmannsverse . . ."79 Tonio examines this man's outpourings, compares them with his own efforts, and "sees clearly demonstrated the articulation of feeling, the control of emotion which sets him apart from the reddish-blond young man." 80

Such bürgerlich attempts at expression, untutored by method and brought about by melancholy, a bürgerlich trait, result in banality and, upon reflection, in a sense of shame and guilt. To the Bürger, there is something wrong about the urge to create, and the following morning the young man from Hamburg, upon seeing Tonio, blushes rosy-red for shame of the poetic indiscretions he had been betrayed into by the dark. He puts on a bluff front and afterwards studiously avoids Tonio.

The non-introspective individual, the Bürger, tends to view the Künstler with a jaundiced eye. There is some-

\footnotetext{
79 Mann; G.W., VIII, p. 320.

80 Wilson, p. 285.
} 
thing shameful and morally wrong about the world of the Künstler. They, are, after all, something akin to "gypsies in green wagons." Their creations, their poetical efforts, are therefore also subject to strong suspicion. If the otherwise good and upright member of the buirgerlich world attempts to produce something "artistic," he is met by both pity and contempt from the Kunstler, who knows what artistic creation actually entails, and by shame and guilt from him fellow Bürger. We see this earlier in the Novelle, when Tonio recalls to Iisaveta a party he had once attended. At the party an officer, a lieutenant, got up and read some of his own verses. "Nun, es erfolgt, was erfolgen muß," Tonio says, "lange Gesichter, Stillschweigen, ein wenig künstlicher Beifall und tiefstes MiBbehagen ringsum."81

Guilt and pity are there, for this Bürger, this officer, this formerly upright and respected member of his community has just demonstrated to his peers that his character is flawed, that his moral health is impaired. The public reaction is similar to the reaction of Hesse's narrator to the Steppenwolf: "Ich spürte (und meine Tante, die im Gegensatz zu mir ja ganz und gar kein intellektueller Mensch ist, spürte ziemlich genau dasselbe)--ich spürte, daß der Mann krank sei, auf irgendeine Art geistes- oder gemüts- oder charakterkrank, und wehrte mich dagegen mit dem

81 Mann, G.W., VIII, p. 304. 
Instinkt des Gesunden."82

Nietzsche has. written, "Es sind die Ausnahme-Zustände, die den Kunstler bedingen: alle, die mit krankhaften Erscheinungen tief verwandt und verwachsen sind: so daß es nicht möglich scheint, Künstler $\mathrm{zu}$ sein und nicht krank zu sein."83. In the episode with the lieutenant, we see part of Mann's belief that the Kunstler's character is somehow "flawed," is somehow "diseased." Those people who are "flawed" are subject to pity, but are at the same time avoided. Glebe writes that Mann

had been shown that of all human beings the artist was doomed to suffer most. He had come to understand that the artist is never normal in the mundane sense--he is, so to speak, deformed, "diseased," his very calling is a disease. Yet he must continue to live or, at least, human nature demanded that he make an attempt to go on living in spite of his divergence from the normal and healthy.

But pity is not the only emotion that is felt for the poor, "diseased" officer. Shame and guilt are also there, and the reasons are clear. To the Bürger, the Künstler's flaw is more than a mere disease.

Thomas Mann distinguishes between the reflectiveanalytic artist, the "Literat," and the sensuous-creative artist, the "Künstler." The Künstler, usually found among the sculptors and painters, is "a gay Bohemian who is amoral,

82 Hesse, G.S., IV, pp. 192-93.

83 Nietzsche, Aus dem Nachlass der Achtzigerjahre, in Werke in drei Bänden, III, 715 .

84 Glebe, p. 262. 
childlike, innocent, irresponsible, and interested in 'bright aspects of life.'"85 We have seen this sensuous/ reflective division not only among the story's characters (Lisaveta vs. Tonio), but also within Tonio himself. Upon his arrival in Munich, "er geriet in Abenteuer des Fleisches, stieg tief hinab in Wollust und heiße Schuld und litt unsäglich dabei. . . Ein Ekel und Haß gegen die Sinne erfaßte ihn und ein Lechzen nach Reinheit und wohlanständigem Frieden. . . . So kam es nur dahin, daß er, haltlós zwischen krassen Extremen, zwischen eisiger Geistigkeit und verzehrender Sinnenglut hin und her geworfen . . . ein erschöpfendes Leben führte. . . ."86

The Bürger, however, does not make much note of these divisions. To him, all Künstler are the same. There is certainly something illicit, something morally wrong, something criminal about such a life, as if all the Künstler had ".a wagonful of travelling gypsies for ancestors."

Tonio himself confirms this view with a story of a banker who had a gift for writing stories. This man was thrown into prison "aus triftigen Gründen" and "es geschah ganz eigentlich erst" in der Strafanstalt, daß er seine Begabung inne wurde." Tonio hints that it was not the prison experience that opened up this man's talents. "Aber drängt sich nicht der Verdacht auf, daß seine Erlebnisse im Zucht-

85 Daemmrich, p. 28.

86 Mann, G.W., VIII, pp. 290-91. 
hause weniger innig mit den Wurzeln und Ursprüngen seiner Künstlerschaft verwachsen gewesen sein möchten als das, was ihn hineinbrachte?" 87 The artistic inclination is, then, in a sense, a criminal trait.

In an interview, Willie sutton, the legendary bank robber, pondered, "I wonder if someone can be born with a criminal mind? Because even as a little boy, when all the other little boys were playing baseball, I was thinking about robbery. I was 10 years old the first time I robbed a joint." 88 Mann was suggesting a connection between the Künstler and the criminal, and it is interesting to note that the practitioners of both of these arts have suggested that the trait is inborn, that it is the person's "fate." Such a comparison heighten's Tonio's assertion that the Künstler cannot be a normal member of the Bürger society. "Ein Bankier, der Novellen dichtet, das ist eine Rarität, nicht wahr? Aber ein nicht krimineller, ein unbescholtener und solider Bankier, welcher Novellen dichtete,--das kommt nicht vor." 89

Standing outside the normal, burgerlich world then are those to be pities and censured: the sick and the criminal-and the Kunstler.

If the Künstler, then, must remain outside the bürger-

87 Mann, G.W., VIII, pp. 298-99.

88 Bob Greene, "Thieves Today Lacking Finesse," The Oregonian, 4 May 1979, p. D4, col. 1. 89 Mann, G.W., VIII, p. 299. 
lich world, what path is open to him? Only one--abandonment of any aspiration to a normal life; struggle, suffering, pain. The Künstler, like Hesse's Knulp, must remain a vagabond who cannot settle into the ordinary life, and the tragedy; Bernhard Zeller writes, is this: "Freedom from the bonds that tie others down can only be bought by foregoing bourgeois happiness, family, and domesticity."90 The inevitable result is suffering, but just because it is inevitable, the Künstler is able to understand and work under its constraints. Mann has written:

Das Talent selbst--war es nicht Schmerz? . . In der Wurzel ist es Bedürfnis, ein kritisches Wissen umdas Ideal, eine Ungenügsamkeit, die sich ihr Können nicht ohne Qual erst schafft und steigert. Und den Größten, den Ungenügsamsten ist ihr Talent die schärfste Geißel . . Nicht klagen! Nicht prahlen! Bescheiden, geduldig denken von dem, was man trug! Und wenn nicht ein Tag in der Woche, nicht eine Stunde von Leiden frei war--was weiter? Die Lasten und Leistungen, die Anforderungen, $\mathrm{Be}-$ schwerden, Strapazen gering achten, klein sehen,-das war's, was groß machte!91

The conclusion is not always one of triumphant success, of overcoming the necessary isolation. William Glebe points to Mann's story "Der.kleime Herr Friedemann" (1905) and comments:

Only in unsatisfied yearning can there be any salvation for the artist. If he is not strong enough to remain alone in an isolated world of his own making, if he attempts to become an integral part of that other world which despises him and excludes him, he meets tragedy. There is no middle way as yet: the choice is either suffering in iso-

90 Zeller, Portrait of Hesse, p. 79.

91 Mann, G.W., VIII, pp. 375-76. 

lation and Ioneliness or a return to nothingness-
death. 92

This, then, is the Künstler's solution. "The true artist cannot live a full life and create great works of art at the same time; therefore, in a sense, he 'dies." 93 We find this theme in Tonio Kröger. Tonio comes to Munich, struggles, and succeeds, and out of his struggle comes the realization "daß gute Werke nur unter dem Druck eines schlimmen Lebens entstehen, daß, wer lebt, nicht arbeitet, und daß man gestorben sein muß, um ganz ein Schaffender zu sein." 94

Willa schmidt tells us, "The change taking place is no casual thing. Tonio must give himself up completely; he becomes a sacrifice to art." 95 However, we must remember that death, for the Kuinstler, is not a negative force, but is rather part of his creative condition. In Klingsors letzter Sommer, Hesse has argued this point. Klingsor both fears and loves death, and Mileck tells us that

he does so for good reason. It is to death that he owes his all. Death is the positive thrust in his life and in his art. Bu,t for his fear of death, he would not live as intensively as he does and has always wanted to, and but for death he would not be the artist that he is. Thanks to death, his life is the blissful agony he actually wants it to be. 96

92 Glebe, p. 262

93 Willa Schmidt, "The 'Wiedersehen' Motif in the Works of Thomas Mann," Monatshefte, 65 (1973), 147.

94 Mann, G.W., VIII, p. 291-92.

95 Schmidt, p. 147.

96 Mileck, p. 154. 
Heinz Kohut further confirms this impression of the value of death to the Künstler when he states,

In the story Tonio Kröger . . . death, or the sympathy for death, seems to gain its significance not so much from any expressed value of its own but rather from an aristocratic negation of life. Tonio Kröger feels it necessary to divorce himself from life; he can remain artistically active and creative only inasmuch as he ceases to be a human being.

This theme, states Kohut, is drawn from German Iiterary history, for it was the

creed of the German romanticists that there is a close affinity between beauty and death. The romantic artist must be dead, symbolically, in order to be able to create a work of beauty. 97

The artistic world is seen to be in a manifold isolation from the bürgerlich world. According to the Bürger, the Künstler must be diseased or criminal. In the Künstler's mind, he himself must be "dead" to the normal world. All three facets are necessarily isolated from the normal, living, bürgerlich world. It is a necessary ingredient of being a Künstler. Still, we must not fail to realize that each of these groups is capable of forming its own unique community. The criminals have their prisons, the diseased have their hospitals, and even the dead have their graveyards. Even the "dead to life," the artistic world, forms its own community. E.M. Wilkinson reminds us, "To have died'. is only one stage in the process of artistic creation; and for the artist to cut himself off from life altogether

97 Heinz Kohut, "'Death in Venice' by Thomas Mann: A Story about the Disintegration of Artistic Sublimation," Psychoanalytic Quarterly, 26 (1957), 219. 
means going out into the waste land of pure form and art for art's sake."98 To those Künstler who have not done so, who have not committed this total suicide, there is still a living community to provide support and fullness: the community of the Kunstler. The concept of the artistic world as a community is supported by Glebe in a discussion of Mann's story "The Dilettante." The Dilettante has semi-artistic talents, which "makes him suspect in the eyes of the bourgeois world and results in his being forced, eventually, out of that world into isolation; the fact that he has them, but not in sufficient measure, precludes him from joining the ranks of those who can practice their art in disciplined fashion and thus win acclaim from their own kind if from no one eise." 99

Within the artistic world, there is acclaim to be won, and therefore there is no sense of isolation, and yet Tonio Kröger is isolated from this world, too, through the bürgerlich sensibilities inherited from his father. The drama and poignancy of this Novelle is highlighted by our realization that Tonio is not simply "ein Bürger auf Irrwegen, ein verirrter Bürger." Tonio is an artist by temperament, and therefore isolated from the bürgerlich world, and yet his bürgerlich longings and sympathies isolate him from his artistic contemporaries. This isolation from both worlds Wilkinson, p. 26. 99 Glebe, p. 267. 
$\cdot \overline{\overline{\tau \tau \partial \Lambda O N}}$

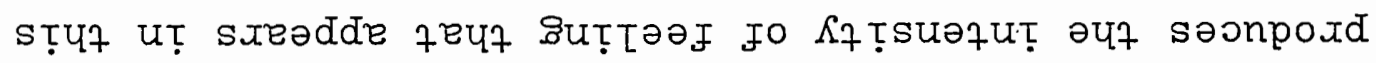




\section{CHAPTER IV}

\section{THE ORIGINS OF ISOLATION}

\section{In Steppenwolf, Hermine tells Harry:}

Du hattest ein Bild vom Leben in dir, einen Glauben, eine Forderung, du warst $\mathrm{zu}$ Taten, Leiden und Opfern bereit--und dann merktest du allmählich, daß die Welt gar keine Taten und Opfer und dergleichen von dir verlangt, daß das Leben keine heroische Dichtung ist, mit Heldenrollen und dergleichen, sondern eine bürgerliche gute Stube, wo man mit Essen und Trinken, Kaffee und Strickstrumpf, Tarockspiel und Radiomusik vollkommen zufrieden ist. Und wer das andere will und in sich hat, das Heldenhafte und Schöne, die Verehrung der großen Dichter oder die Verehrung der Heiligen, der ist ein Narr und ein Ritter Don Quichotte. . . Das Leben, dachte ich, muß doch schließlich immer recht haben, und wenn das Leben meine schöne Träume verhöhnte, so dachte ich, es werden eben meine Träume dumm gewesen sein und unrecht gehabt haben. Aber das half gar nichts. Und weil ich gute Augen und Ohren hatte und auch etwas neugierig war, sah ich mir das sogenannte Leben recht genau an, meine Bekannten und Nachbarn, fünfzig und mehr Menschen und Schicksale, und da sah ich, Harry: meine Träume hatten recht gehabt, tausendmal recht, ebenso wie deine. D五oLeben aber, die Wirklichkeit, hatte unrecht. . .

From his very youth, Tonio Kröger had a picture of life within him, and gradually he, too, came to realize that the world did not demand anything of him, and even indeed cursed and feared him for his dreams. This bürgerlich reaction is typical, as evident in the words of the narrator of Hesse's Steppenwolf, who states, "Ich . . fühle mich durch ihn, durch die bloße Existenz eines solchen Wesens, 
im Grunde gestört und unberuhigt, obwohl er mir geradezu lieb geworden ist." ${ }^{101}$ And it was this effect that set Tonio apart, for with this awareness of the world's indifference "kam . . die Einsamkeit, weil es ihn im Kreise der Harmlosen mit dem fröhlich dunklen Sinn nicht litt und das Mal an seiner stirn sie verstorte."102

Tschol-Za Kim writes of the significance of this "Mark of Cain." He states, "Das Anderssein Tonios bezeichnet Thomas Mann noch einmal damit, daß Tonio ein «Mal an seiner Stirn» trüge. Wie ein Künstler trotz des Males an seiner Stirn als Mensch mit dem normalen Leben fertig werden soll, ist ein weiteres . . Probleme des Künstlertums bei Thomas Mann."103 An explanation of the origin of the "Mark of Cain" was offered by Hesse in his 1925 novel Demian:

Das, was vorhanden war und womit die Geschichte ihren Anfang genommen hat, war das Zeichen. Es war da ein Mann, der hatte etwas im Gesicht, was den andern Angst machte. Sie wagten nicht, ihn anzurühren, er imponierte ihnen, er und seine Kinder. Vielleicht, oder sicher, war es aber nicht wirklich ein Zeichen auf der Stirn, so wie ein Poststempel, so grob geht es im Leben selten zu. Viel eher war es etwas kaum wahrnehmbares Unheimliches, ein wenig mehr Geist und Kühnheit im Blick, als die Leute gewohnt waren. Dieser Mann hatte Macht, vor diesem Mann scheute man sich. Er hatte ein, Zeichen'. Man konnte das erklären, wie man wollte. 'Und ,man' will immer das, was einem bequem ist und recht gibt. Mian hatte Furcht vor den Kainskindern, sie hatten ein 'Zeichen'. Also erklärte man das Zeichen seien nicht als das, was es war, als eine Auszeichnung, sondern

101 Hesse, G.S., IV, pp. 189-90.

102 Mann, G.W., VIII, p. 290.

103 Tschol-Za Kim, "Natur und Geist bei Thomas Mann," Colloquia Germanica, i-ii (1975), 77. 
als das Gegenteil. Man sagte, die Kerls mit diesem Zeichen seien unheimlich, und das waren sie auch. Leute mit Mut und Charakter sind den anderen Leuten immer sehr unheimlich. Daß da ein Geschlecht von Furchtlosen und Unheimlichen herumlief, war sehr unbequem, und nun hängte man diesem Geschlecht einen Übernamen und eine Fabel an, um sich an ihm zu rächen, um sich für alle die ausgestandne Furcht ein bißchen schadlos zu halten.

Golo Mann tells us that his father "believed that great artists had to have a powerful self-confidence and consciousness of themselves, and that they must think of themselves as being somehow set apart in order to create, and he also thought that if they did not have such a consciousness of themselves they would not be able to win through. Clearly he himself had such a consciousness of himself."105 We feel the poignancy of this self-consciousness in Tonio's words:

Sie fangen an, sich gezeichnet, sich in einem rätselhaften Gegensatz zu den anderen, den Gewöhnlichen, den Ordentlichen zu fühlen, der Abgrund... der sie von den Menschen trennt, klafft tiefer und tiefer, Sie sind einsam, und fortan gibt es keine Verständigung mehr. Was für ein Schicksal!. . . Ihr Selbstbewußtsein entzündet sich, weil Sie unter Tausenden das Zeichen an Ihrer Stirne spüren und fühlen, daß es niemandem entgeht. . . . Das Gefühl der. Separation und Unzugehörigkeit, des Erkannt- und Beobachtetseins . . . ist in . . Gesicht. . . Aber da hilft kein Zivil, Lisaweta! . . . Sie werden kaum die Augen aufzuschlagen und ein Wort zu sprechen brauchen, und jedermann wird wissen, daß Sie kein Mensch sind, sondefn irgend etwas Fremdes, Befremdendes, Anderes.

104

Hesse, G.S., III, pp. 125-26.

105 Golo Mann, pp. 14-15.

106 Thomas Mann, G.W., VIII, pp. 297-98. 
The awareness is there, the awareness that you are different, and the behavior induced by this awareness marks you. You are noticed, as Hesse's Demian was noticed: "Ich sah nur: er war anders als wir, er war wie ein Tier, oder wie ein Geist, oder wie ein Bild, ich weiß nicht, wie er war, aber er war anders, unausdenkbar anders als wir alle."10? But what happens when one is queer, different, artistic? One finds relief only in artistic expression, a dis-. passionate examination of the world and one's feelings about it. "A psychological process ensues in which every observation is analyzed with respect to its literary possibilities. Seeing is converted into cognition which upon further reflection becomes the basis for artistic production."108 Communication with fellow beings is withdrawn, thoughts turn inward. Tonio considers his world: "Und er schrieb diesen Gedanken innerlich auf, dachte ihn völlig aus und empfand inn bis auf den Grund."109

Once a thought is completely and dispassionately examined, it can be expressed, and once expressed, it needs no further consideration. For the Künstler, the thought has been fully considered and can not nor need not be changed or retracted. But this is not true, for life is full of contradictions and retractions and denials, and it is this di-

\footnotetext{
107 Hesse, G.S., III, p. 147.

108 Daemmrich, p. 35.

109 Mann, G.W., VIII, p. 288.
} 
chotomy between the complete expression and the incomplete world that brings such isolation to Tonio Kröger. He begins his. journey to enlightenment even as he voices his belief: "Sehen Sie, der. Iiterat begreift im Grunde nicht, daß das Leben noch fortfahren mag, zu leben, daß es sich dessen nicht schämt, nachdem es doch ausgesprochen und «erledigt» ist. Aber siehe da, es sündigt trotz aller Erlösung durch die Iiteratur unentwegt darauf los; denn alles Handeln ist Sünde in den Augen des Geistes."110

This, then, is the cause to Tonio's isolation. Tonio is a literary man and his behavior is patterned in just this fashion. He believes a thought, once expressed, is finished, unalterable. To express is to bare one's soul. And so it is--for the literary man. But we must remember that in Tonio Kröger, Thomas Mann is attempting to describe both the "shaping" phase of artistic creation and the "seeing" phase which precedes it. Not everyone is equally aware of this "seeing" phase, a "special kind of awareness of the universe."1ll The untutored mind notices only the moment "Thomas Mann holds fast for us . . . when this watching trembles on the brink of becoming literature, the transition from awareness to the communication of it through the medium of words." 112 Tonio has literary awareness, but he fails to

110 Mann, G.W., VIII, p. 302

111 wilkinson, p. 22.

112 wilkinson, p. 24. 
understand that the undisciplined mind knows little of this special aesthetic experience. To the Bürger, and to the average Künstler, most conversations are social events. "Talking" is more important than "saying something significant." Thus if one has considered something thoroughly, has come to a conclusion, and attempts to communicate these thoughts, the results are often futile. The expressed thoughts form part of the conversation, but the significance of the words remains isolated in the mind of the originator. The expressed thought changes nothing: life continues as if the statement had not been made.

Tonio has been led astray by his vision of life which conflicted with his desire and ability to be like others. He has been torn by the feeling expressed in steppenwolf by Hermine: "Das Leben, dachte ich, muß doch schließlich immer recht haben, und wenn das Leben meine schönen Träume verhöhnte, so dachte ich, es werden eben meine Träume dumm gewesen sein und unrecht gehabt haben. Aber das half gar nichts."113 Tonio's confusion is evident, and because he cannot come to any dispassionate conclusion or control of his feelings, he seeks out lisaveta and pleads for help. He sincerely wants her advice; as a literary man, he "bares his soul" to her and states, "Aber ich beschwöre Sie, halten Sie es nicht für Literatur, was ich da sage!" 114 what

113 Hesse, G.S., IV, pp. 342-43.

114 Mann, G.W., VIII, p. 302. 
happens then? Henry Hatfield tells us, "Lisaveta Ivanovna, his confidante, makes him recognize his true position for the first time. He is a bourgeois after all, but a 'lost burgher,' a 'Bohemian with a bad conscience.' This insight, strategically placed in the center of the novella, is its turning point." 115

This is, indeed, the turning point, and it is certain that Iisaveta's analysis of his problem has an entirely different significance to Tonio. Wilkinson tells us, "When Lisaveta speaks of the 'redeeming power of the word,' she surely means that through his medium the artist's insight becomes manifestly fruitful. But again Tonio chooses to ignore the rewards and to dwell rather on the toll which the artist must pay for having surrendered to the power of his medium, a toll paid in sterility and isolation."1l6 Tonio has known he is not of the bürgerlich world, although he longs for it. Her words now tell him that even she, a fellow member of the artistic world, speaks with an understanding other than his. He is not of her world; therefore, she seems to say, he must be of the Buirger, if only on a wrong path. He now realizes that this life, too, may be wrong. His dreams are not stupid but only unrealizable also in this world. "Ich danke Ihnen, Iisaweta Iwanowna," he says, "nun kann ich getrost nach Hause gehn. Ich bin er-

115 Hatfield, p. 54.

116 Wilkinson, p. 24. 
ledigt." 117 He has expressed himself, but he no longer believes that this world is listening to him.

Tonio has come a long way to this realization of the indifference of the world to his expression. Tschol-Za Kim writes, "Eines der großen Lebensanliegen Thomas Manns ist zu zeigen, daß der Künstler oder schon der irgendwie künstlerisch veranlagte Mensch von den normalen «amusischen» Menschen so sehr schicksalhaft verschieden ist, weil er sich selbst schon von früh an anders als die allgemeinen Menschen empfindet und weil er selbst weiß, daß dies Anderssein seine Anschauung und sein Wesen beeinflußt hat." 118 We see this also in Tonio Kröger.

As a child, Tonio's artistic inclinations led him to the beautiful, and yet his attempts to express himself to others were met with indifference or only feigned interest. Hans Hansen accepted Tonio's recommendations to read Don Carlos only out of his desire for friendship with another of his class and out of his admiration for Tonio's ability to put certain difficult matters into words. Hans's spiritual comradeship is saved for Irwin Immerthal, a fellow Bürger and horse-lover. Tonio blames his own inability to communicate with Hans upon his own artistic inclinations, on his lack of appreciation of the bürgerlich sensibilities. Of this relationship between the two boys, Wilkinson writes:

\section{$118 \mathrm{Kim}, \mathrm{p} .75$.}

117 Mann, G.W., VIII, p. 305. 
Tonio knows well enough that it is a relation which can never bring fulfilment, a love in which all the longing and burning, all attempts at closeness and all torture at their frustration, will be on one side. But he knows far more than this. And it is just in this more that the quality of awareness emerges most clearly. For even at fourteen he senses the universality held within this personal experience. 119

Tonio suffers because of his special awareness, and we are told, "Ja, es war in allen Stïcken etwas Besonderes mit ihm, ob er wollte oder nicht, und er war allein und ausgeschlossen von den Ordentlichen und Gewöhnlichen. . . ."120 Thus, when Hans, the normal Bürger, responds even slightly to him by agreeing. to read Schiller, Tonio is touched, and we read: "Damals lebte sein Herz; Sehnsucht war darin und schwermütiger Neid und ein klein wenig Verachtung und eine ganze keusche Seligkeit."121 Yet these are bürgerlich qualities rising in Tonio's soul, and the reader feels the contrast with the echoes from Don Carlos of the words of Schiller's king:

\section{Anders,}

Begreif ich wohl, als sonst in Menschenköpfen, Malt sich in diesem Kopf die Welt.

Tonio later fixes his attentions upon Ingeborg Holm, and again he feels the frustration of being sensually aligned to a person without being spiritually connected. Is it always so, that sensual attractiveness precludes spiritual

119 wilkinson, p. 23.

120 Mann, G.W., VIII, p. 279.

121 Mann, G.W., VIII, p. 281. 
kinship? Tonio admired Hans, and found him incapable of thinking. Tonio falls for Inge, lovely, blonde Inge, and she has eyes only for the superficial, banal Herrn Knaak, the dancing master. Hans's admiration for Irwin and Inge's admiration for Herm Knaak, thinks Tonio, are honest, bürgerlich feelings, and that "gewann ihm im Grunde etwas wie Bewunderung $a b$. . . Er verstand es so gut, daß Inge, die blonde, süße Inge, auf Herrn Knaak blickte, wie sie es tat."122 And yet we see that even at this young age, Tonio is turning away from the buirgerlich world. Wilkinson states this: "Even as early as his love for Inge, Tonio realized that he must be in some sense remote from an experience in order to be able to 'form' it into literature, remote, not in space or time, but in attitude."123 At first, Tonio's romantic longings capture his feelings for Inge. "Ein wunderschönes Gedicht von Storm fiel ihm ein: «Ich möchte schlafen, aber du mußt tanzen.»"124 Then, Tonio comes to realize, "So schön und heiter wie du kann man nur sein, wenn man nicht «Immensee» liest und niemals versucht, selbst dergleichen zu machen; das ist das Traurige! "125

The symbol of the dance plays an important part in the structure of this story. Kenneth Wilson relates: "The old,

\footnotetext{
122 Mann, G.W., VIII, p. 284.

123 Wilkinson, p. 24.

124 Mann, G.W., VIII, p. 285.

125 Mann, G.W., VIII, p. 286.
} 
honored metaphor of life as dance is a basis of both structure and theme in Thomas Mann's Tonio Kröger. . . Mann . . . uses as symbol the quadrille, a civilized dance of couples, a 'society' square dance."126 This dance is appropriate, for it involves the necessity of being a couple--a member, rather than an individual--and of being skilled in performing the required movements of the dance. Wilson states, the dancers "must have an instinctive awareness of their relationship to the pattern, because there are so many dancers that one misstep by an awkward individual will destroy the whole ordered pattern of the dance."127 Thus we see the origin of the fear of those who are not normal: a fear for the destruction of the whole dance. Furthermore, Wilson points out that "the thread of the dance can be broken both by those who cannot master the skills and so fall down in the dance, and by those who cannot close their minds to everything but their part in the dance, and so fail to concentrate themselves into a simple state of emotional and physical expression." 128 Here we see the difference between the Tonios and the Magdalena Vermehrens of the world. Wilson says:

Tonio discovers that he cannot concentrate on the dance: he loves Ingeborg, but only the Hans Hansens can dance with the Ingeborg Holms; only the blueeyed, blond-haired, handsome ones can concentrate

$$
\begin{aligned}
& 126 \text { Wilson, p. } 282 . \\
& 127 \text { Wilson, p. } 282 . \\
& 128 \text { Wilson, p. } 282 .
\end{aligned}
$$


their existence into the single level the dance requires. In Magdalena Vermehren, Tonio sees one of those pitiful, injured souls who fall in the dance. She understands him, she would love him, but her incapacity as dancer is different from his.129

Of her, Patrick O'Neill states, "Magdalena is of the unhappy race of Christian Buddenbrook, fated never to keep step in the dance of life, but without the compensation of creative insight." 130

After Tonio's blunder in the dance, he retires to the shuttered window and gazes into the "opening through which only he with his special perceptivity can see,"131 and he leaves the dancing to the adept. $0^{\prime}$ Neill terms this act a "flight into the: aesthetic sleep-world of Immensee, freed of any obligation to compete with the Hans Hansens and Inge Holms." 132

Eventually, Tonio's feelings of isolation from his bürgerlich upbringing drive him away from Lübeck to Munich, to the artistic world. There he is thrown into a fury of work and fury of life. He was, Mann writes, "haltlos zwischen krassen Extremen, zwischen eisiger Geistigkeit und verzehrender Sinnenglut hin und her geworfen. . ."133 $\mathrm{He}$ finds sensual companionship drawn to him by his artistic

129 Wilson, pp. 283-84.

130 Patrick 0'Neill, "Dance and Counterdance: A Note on Tonio Kröger," German Iife and Letters, 29 (1976), 294.

131 Wilson, p. 284.

132 O'Neill, p. 292.

133 Mann, G.W., VIII, pp. 290-91. 
success. And he believes he has found spiritual companionship in the artistic world, an illusion he is gradually to discover after the novelty has worn off of living in an environment that is free from the moral oppression of "respectability" he faced at home in the north.

He discovers there is more to self-expression than being at one with one's world. He feels contempt for the Künstler who treats his talent like merely another social asset. Gradually he is forced to consider the Künstler and his world and his own relationship to it. What is a kinstler? he asks. And then he shows his contempt even for his own type of individual. He says, "Im Ernst, es hat eine eisige und empörend anmaßliche Bewandtnis mit dieser prompten und oberflächlichen Erledigung des Gefühls durch die literarische Sprache." 134 This contempt toward the Künstler he blames upon his own inborn bürgerlich sensibilities.

Tonio is filled with inner rage at his isolation and at his contempt for the posturings of the Kunstler. He hopes to receive some" support and affirmation of his feelings, and so he goes to see Iisaveta Ivanovna. Lisaveta, he hopes, can at least listen to him, hear him, soothe him. But what happens? He discovers her artistic sensibilities are not his. She tells him, "Nachher gehen wir in den «Salon» 134 Mann, G.W., VIII, p. 301. 
und trinken Tee, und Sie sprechen sich aus. . ."135 She wants him to "talk himself out," but it is not necessarily important that he "say" anything. Tonio talks of the isolation of the Künstler. Her reaction to his effort to express himself, to try to find some understanding, is only this: she replies, "Sie sollten sich ein bißchen schämen, Tonio Kröger. Kommen Sie nun zum Tee."136 She, like Adalbert the novelist, is aware of the artistic isolation necessary for artistic production, but she is also a full, sympathetic member of the artistic community and cannot understand a Künstler who questions the values of his own artistic world. The Bürger is the one who does that, and the Bürger condemns it. The Künstler's task is to examine the bürgerlich world and to express that. A Künstler considering art: Unthinkable: To hear such talk is idle chatter and unnecessary.

Tonio asserts, "Man macht, was die Herkunft, die Miterscheinungen und Bedingungen des Künstlertums betrifft, immer wieder die merkwürdigsten Erfahrungen." To that, she replies, "An anderen, Tonio Kröger--verzeihen Sie--, oder nicht nur an anderen?"137 It is clear that Tonio is saying he is outside this life-style and only an observer. It is equally clear that she cannot understand anything but a

135 Mann, G.W., VIII, p. 294.
136 Mann, G.W., VIII, p. 297.
137 Mann, G.W., VIII, p. 299. 
Buirger as being in the position of observer of the artistic life. There, she thinks, she has solved Tonio's problem. If he insists on being an observer of the artistic life, then he must be on the other side. "Sind Sie nun fertig, Tonio Kröger?" she asks. "Ich habe Thnen gut zugehört. . . . Nun also: Die lösung ist die, daß Sie, wie Sie da sitzen, ganz einfach ein Bürger sind. . . Sie sind ein Bürger auf Irrwegen, Tonio Kröger--ein verirrter Bürger."138

In this statement, Iisaveta criticizes Tonio's inherent Bürgerlichkeit, and we see that she was, indeed, correct. We are told that after Tonio came to Munich, he "arbeitete nicht wie jemand, der arbeitet, um zu leben, sondern wie einer, der nichts will als arbeiten. . . "139 Christa Kamenetsky states of Thomas Mann, "To him Dichtung, or literature as art, implied not only a writer's personal commitment to certain values, but also a mission to which he was happily and unhappily doomed. To be a Dichter was thus a curse as well as a blessing, a metaphysical quest bearing the seeds of destruction and of creation." 140

What this responsibility of being a Künstler meant to Thomas Mann is explained by his son Golo:

Somewhere in a small forgotten essay, he once asks why he writes books and he gives the reply: "For fear of death and for. fear of God". So it was not because of ambition, not so that he would become

138 Mann, G.W., VIII, p. 305.

139 Mann, G.W., VIII, p. 291.

140 Kamenetsky, p. 420. 
famous, not so as to earn money - these were all at most subsidiary motives - but rather it was because it was his duty, as it is everybody's duty, to fulfill his life through work and to make the very most of it. 141

Tonio, however, is oblivious to this Buirgerlichkeit of his artistic drives. He had hoped to find sympathy from Lisaveta, to find something to reconcile himself with the world around him. Here again we see that Tonio is fated to remain outside the dance of life. Wilson points out that "the dancers seek love, and the final position is a claiming of partners. Tonio as would-be dancer begins with Hans Hansen, fails to win him, turns to Ingeborg, fails again, and then seeks Lisabeta, and not as a partner in the usual sense of the dance; with Lisabeta. . . he is simply trying to find a way into the dance... . "142 Tonio blunders in the bürgerlich quadrille, and now he finds he must even remain apart from those who join in the "schweren, schweren und gefährlichen Messertanz der Kunst."

Tonio is crestfallen. He has "expressed" his innermost thoughts and is therefore "finished," and now he realizes that his condition is unique, that even Lisaveta does not understand him. Now he understands only too clearly the feeling expressed in 1919 by Hesse in Demian:

Die Sehnsucht nach Erleichterung, das Verlangen nach einer richtigen Beichte spürte ich oft brennend, und empfand doch auch voraus, daß ich weder vater noch Mutter alles richtig würde sagen und erklären

Golo Mann, p. 16.

142 Wilson, p. 283. 
können. Ich wußte, man würde es freundlich aufnehmen, man wïrde mich sehr schonen, ja bedauern, aber nicht ganz verstehen, und das Ganze würde als eine Art Entgleisung angesehen werden, während es doch Schicksal war. 143

Tonio says, "Ich bin erledigt." He is "expressed" and therewith finished. His artistic insight has now given him a view of his own condition. He realizes that he is neither a Bürger nor a Künstler, if Hans Hansen and Ingeborg Holm are Bürger and Iisaveta and Adalbert are Künstler. Wilkinson maintains that "his final remark. . symbolizes the destruction of a former self." 144 Tonio's past life is, in a sense, finished, and he will soon begin searching for his proper home. His artistic insight has now been applied to his private life.

143 Hesse, G.S., III, p. 131.

144 Wilkinson, p. 25. 


\section{CHAPTER V}

\section{THE REBIRTH OF TONIO KRÖGER}

"To see through his 'crude simplification' of himself, to penetrate the nature of his own ego," writes Boulby of Hesse's Steppenwolf, "it is necessary for Harry to observe himself from another level, to break the vicious circle of one-level thinking in which it is so easy to drown." 145 And so it is for Tonio; thus he commits a "suicide" of sorts when he abandons the only "life" he has known to date, the artistic Iife in Munich. But this "death" is now "a figure for the sacrifice of self-delusion prior to descent into the soul. The death wish, indeed, is intimately connected with something else,. . . with enlightenment."146 Thomas Mann himself writes, "Niemand bleibt ganz, der er ist, indem er sich erkennt." 147

Hermine, in Steppenwolf, tells Harry:

Wer heute leben und seines Lebens froh werden will, der darf kein Mensch sein wie du und ich. Wer statt Gedudel Musik, statt Vergnügen Freude, statt Geld Seele, statt Betrieb echte Arbeit, statt Spielerei echte Leidenschaft verlangt, für den ist diese hübsche Welt hier keine Heimat. . . Ach Harry, wir müssen durch so viel Dreck und Unsinn tappen, um

145 Mark Boulby, Hermann Hesse: His Mind and Art (Ithica: Cornell University Press, 1967), p. 186.

146 Boulby, p. 184 .

147 Mann, G.W., XI, p. 90. 
nach Hause zu kommen! Und wir haben niemand, der uns führt, unser einziger Führer ist das Heimweh. 148

"Our only guide is our homesickness," she states. So it is homesickness that guides Tonio in his renewed search for a place in the world. He returns first to the city and landscape of his youth; we expect and do indeed find that Tonio will review his entire life, but this time with the insight that he has gained. It is important that Tonio review his life to date before moving on to unchartered waters, for as Thomas Mann has written in "Freud und die Zukunft" (1936):

Denn dem Menschen ist am Wiedererkennen gelegen; er möchte das Alte im Neuen wiederfinden und das Typische im Individuellen. Darauf beruht alle Traulichkeit das Lebens, welches als Vollkommenen neu, eimmalig und individuell sich darstellend, ohne daß es die Möglichkeit böte, Artvertrautes darin wieder zufinden, nur erschrecken und verwirren könnte.149

Tonio returns to Iübeck, approaching it as neither a Bürger nor a Künstler. When he walks into his hotel, arriving without ceremony, the porter carefully examines him, "sichtbar bestrebt, ihn gesellschaft ein wenig zu bestimmen, ihn hierarchisch und bürgerlich unterzubringen und ihm einen Platz in ihrer Achtung anzuweisen, ohne doch zu einem beruhigenden Ergebnis gelangen zu können. . . ."150 This symbolically represents the position Tonio has now taken with his life and the world. He no longer is sure Hesse, G.S., IV, pp. $343,346$.

149 Mann, G. in. IX, p. 492.

150 Mann, G.W., VIII, p. 309 
of his place.

Tonio wanders through his old home town in an attempt to find himself, and again we see traces of the "dance of Iife" metaphor. As a boy, Tonio had wooed Hans Hansen during their walk home from school. Of that incident, Wilson writes: "The boy Tonio slips his arm into Hans Hansen's and the after-school walk is a troubled dance. . . and for a time things go well and the pattern seems outwardly correct. . . Then Irwin Immerthal interrupts, and Tonio is outside once more."151 Now Tonio is back in Lübeck, and Wilson comments: "He still walks slowly, according to his own rhythm, which is not the rhythm of the dancers; he still cannot lose himself in the dance, but views it from a distance, always thinking, watching, weighing. His experiences are not the same as the dancers' experiences." 152

Tonio visits his ancestral home and discovers it has become a public library. He is amazed. "Volksbibliothek? dachte Tonio Kröger, denn er fand, daß hier weder das Volk noch die Iiteratur etwas zu suchen hatten. "153 His books, his artistic self, have preceeded him home; the Bürger and the Künstler are both at home there, yet he is not. This homecoming has made more clear to Tonio what Willa Schmidt has termed "the unmendable rift which had arisen be-
151 Wilson, p. 284.
152 wilson, p. 285.
153 Mann, G.W., VIII, p. 312. 
tween the hero and his past as a result of his special development." 154 And yet, as Wilkinson reminds us, when Tonio "sees the old house, symbol of the burgher's way of life, filled with books, children begotten of the spirit, what a revelation it must seem of the way he ought to go!"155

Wilson comments that Tonio "has already returned home really, for his books are on the shelf of the library his townsmen have made of his father's house, but, ironically, Tonio the man is unrecognized and unwelcomed. He is viewed with suspicion at every point. . . He is not like other men, and so he is misunderstood."156 This misunderstanding climaxes in Tonio's near arrest at his hotel, and this episode serves to underscore Thomas Mann's belief that "Art is illusion: her magic is that 'her form consumes material content!' Art is not accountable to reality. . . "15?

Reed underscores that "the effect-seeking of the artist is part of his charlatanry and illusionism, and hence a self-reproach for one who feels, like Tonio Kröger, that he has sacrificed human substance and human relations to his art."158 The theme of art as a deceptive illusion is also presented by Thomas Mann in his novel Felix Krull, and with

154 Schmidt, p. 154 .

155 Wilkinson, pp. 25-26.

156 Wilson, p. 285.

157 Daemmrich, p. 31.

158 Reed, p. 77. 
this understanding, Reed writes: "Tonio Kröger had been nearly arrested as a criminal on his return home to the north, and had felt the higher appropriateness of the error."159 "Und waren diese Männer der bürgerlichen ordnung," Tonio says, "nicht im Grunde ein wenig im Recht? Gewissermaßen war er ganz einverstanden mit ihnen." 160

Tonio crosses the sea to Denmark, and on the boaj, the intensity of feeling that has gripped him, this "homesickness," prompts him to artistic effort, and within himself, he chants to the sea: "Du meiner Jugend wilder Freund, so sind wir einmal noch vereint. . Aber dann war das Gedicht zu Ende. Es ward nicht fertig, nicht rund geformt und nicht in Gelassenheit zu etwas Ganzem geschmiedet. Sein Herz lebte." 161 Much as he has now physically passed beyond both bürgerlich Lübeck and artistic Munich, so is he being mentally prepared for a new insight that is neither bürgerlich nor artistic. His heart lives, and he must be reborn.

He comes to Aalsgaard, where we see his symbolic rebirth and the awakening of his awareness. The "raw elements of nature" prepare him for this re-emergence. In Lübeck on the day of his departure, we read, "Des Himmels schon ein wenig blasses spätsommer-Blau war von dünnen, vom wind zerzupften Wolkenfetzchen durchzogen; aber die Sonne schien

159 Reed, p. 109.

160 Mann, G.W., VIII, p. 317.

161 Mann, G.W., VIII, pp. 321-22. 
über seiner Vaterstadt."162 on the boat to Denmark, Tonio "Lehnte den Kopf gegen den starken Salzwind, der frei und ohne Hindernis daherkam, die Ohren ümhüllte und einen gelinden Schwindel, eine gedämpfte Betäubung hervorrief, in der die Erinnerung an alles Böse, an Qual und Irrsal, an Wollen und Mühen träge und selig unterging. . . . Es dunkelte mehr und mehr."163 on the boat trip from Copenhagen to Aalsgaard, he "fuhr an einem trüben Tage (die See ging schwarz) nordwärts. . . ."164

In Aalsgaard, Tonio returns to the nothingness of the void, the raw'elements out of which he will attempt to create a new place for himself in the world. There, on the shore, he stands "in Wind und Brausen eingehüllt, versunken in dies ewige, schwere, betäubende Getöse, das er so sehr liebte."165 This image is familiar in Mann's works. It appears later in "Tod in Venedig":

Er liebte das Meer aus tiefen Gründen: aus dem Ruheverlangen des schwer arbeitenden Künstlers, der vor der anspruchsvollen Vielgestalt der Erscheinungen an der. Brust des Einfachen, Ungeheueren sich $\mathrm{zu}$ bergen begehrt; aus einem verbotenen, seiner Aufgabe gerade entgegengesetzten und eben darum verführerischen Hange zum Ungegliederten, Maßlosen, Ewigen, zum Nichts. Am Vollkommenen zu ruhen, ist die Sehnsucht dessen, der sich um das Vortreffliche müht; und ist nicht das Nichts eine Form des Vollkommenen?166

\footnotetext{
162 Mann, G.W., VIII, p. 309-10.

163 Mann, G.W., VIII, p. 319.

164 Mann, G.W., VIII, p. 323.

165 Mann, G.W., VIII, p. 325.

166 Mann, G.W., VIII, p. 475.
} 
And thus it is that Tonio descends into the nothingness, but as Mann writes in "Schwere Stunde," "Nicht ins Chaos hinabsteigen, sich wenigstens nicht dort aufhalten: Sondern aus dem Chaos, welches die Fïlle ist, ans Iicht emporheben, was fähig und reif ist, Form zu gewinnen."167

Out of this natural setting one day, by some chance association, Tonio "erinnerte sich flüchtig eines fernen Bekannten, Adalberts, des Novellisten, der wußte, was er wollte. . . Und er zuckte die Achseln uber ihn."168 Tonio is no longer a Künstler, for they too, like the Bürger, "know what they want." Tonio has overcome the burgerlich Lïbeck, and now he has also overcome the artistic world of the Adalberts.

We come now to the magical day of awakening. Tonio "Erwachte sehr früh und ganz plötzlich, fuhr mit einem feinen und unbestimmten Erschrecken aus dem Schlafe empor und glaubte, in ein wunder, einen feenhaften Beleuchtungszauber hineinzublicken. . . Als er aber vor der Glastür stand und hinausblickte, sah er, daß es die Sonne war, die aufging."169 Here, Mann is telling us that Tonio will finally gain insight into his condition, that finally "ein licht geht auf." Tonio feels this, and at the breakfast table, he comments,

167 Mann, G.W., VIII, p. 379.

168 Mann, G.W., VIII, p. 329.

169 Mann, G.W., VIII, p. 326. 
"Das ist eine hübsche Abwechslung." 170 "Da geschah dies auf einmal: Hans Hansen und Ingeborg Holm gingen durch den Saal." 171 How will he react to them? Once again, he suspects what will happen, and repeats, "Das ist eine hübsche Abwechslung. " 172

Tonio observes the carefree, happy companionship of these two and the other guests, and realizes at long last that the longings he has now and had as a child are not the longings for these particular people, but for what they represent. Tschol-Za Kim confirms this: "Tonio gesteht vor Lisaweta: "Ich liebe das Leben». Tonio liebt aber nicht alle Arten und Formen des Lebens, sondern allein das Leben, das dem Bürgertum angehört."173 He tells us, "Tonio liebt Hans Hansen und Ingeborg Holm deshalb, weil sie anders sind als er, aber gerade in der Art anders, als es ihm gefällt."174 Mann explains, "Sie waren es nicht so sehr vermöge einzelner Merkmale und der Ähnlichkeit der Kleidung, als Kraft der Gleichheit der Rasse und des Typus, dieser lichten, stahlblauäugigen und blondhaarigen Art, die eine Vorstellung von Reinheit, Ungetrübtheit, Heiterkeit und einer zugleich stol-

170 Mann, G.W., VIII, p. 327.

171 Mann, G.W., VIII, p. 327.

172 Mann, G.W., VIII, p. 328.

$173 \mathrm{Kim}, \mathrm{p} .76$.

$174 \mathrm{Kim}, \mathrm{p} .76$. 
zen und schlichten, umbexührbaren Sprödigkeit hervorrief."175 Tonio no longer desires to convert them to his viewpoint. His insight has shown him that he can't do that, but he still wishes he could be like them. He laments, "Zu sein wie du! Noch einmal anfangen, aufwachsen gleich dir, rechtschaffen, fröhlich und schlicht, regelrecht, ordnungsgemäß und im Einverständnis mit Gott und der Welt, geliebt werden von den Harmlosen und Glücklichen . . frei vom Fluch der Erkenntnis und der schöpferischen Qual leben, lieben und Ioben in seliger Gewöhnlichkeit!"176

He is, however, now aware that it would do him no good to begin again, for with him it would turn out again as it has before. "Denn e.tIiche gehen mit Notwendigkeit in die Irre, weil es einen rechten Weg für sie überhaupt nicht gibt." 177 He realizes that it was not his fault that Hans and Inge never understood him, just as Iisaveta never understood what he was trying to say. These others lived in their worlds, and he was part of neither of them. Talking to them, trying to convey his feelings to them would not work, for "sie würden ihn nicht verstehen, würden befremdet auf das horchen, was er zu sagen vermöchte. Denn ihre Sprache war nicht seine sprache."178

$$
\begin{aligned}
& 175 \text { Mann, G.W., VIII, p. } 331 . \\
& 176 \text { Mann, G.W., VIII, p. } 332 . \\
& 177 \text { Mann, G.W., VIII, p. } 332 . \\
& 178 \text { Mann, G.W., VIII, p. } 333 .
\end{aligned}
$$


Tonio has gained insight now, and when during the dance in Denmark the same longings strike him as they did at Herr Knaak's dancing class, he recognizes the differences. "Tonio, we notice, does not actually take part in this second dance: the artist is of necessity one who stands outside the dance of life--but, quite simply, Tonio has learned to accept it."179 His memories are stirred, and again he thinks of Storm's "Ich möchte schlafen, aber du mußt tanzen." However, as O'Neill points out, when "Tonio first quoted Storm, the image of the dance had the old-established connotation of the dance of life. . . By the time he thinks of the line again the dance suggests not the merry dance of life but the 'schweren, schweren und gefährlichen Messertanz der Kunst.'"180

Once again, Tonio escapes from the dance by retreating into thought. However, when he had fled the earlier dance, he attempted to gaze moodily out of a window, without noticing that the blinds were closed. Now he is aware that "art cannot--and must not--become a substitute for the dance of life. At the later dance the window has become a glass door --and 'die Glastür. . . stand geöffnet'. . . . Here once again, then, the theme of synthesis is clearly expressed... the glass door contains the images of both isolation and

179 O'Neill, p. 294.

180 O'Neill, p. 293. 
communication."181 Tonio is at last aware of where he stands. He awareness is reflected in the words of Hesse's Steppenwolf: "Plötzlich eine Tür offen, durch die das Leben zu mir hereinkam!" 182

Tonio is no longer of the world of Hans and Inge, nor of the world of Lisaveta and Adalbert. He has passed through those levels on his "Weg nach Innen." Hughes states: "Humanization, as we have seen, is not merely sensual refinement, but also the concomitant advance to a higher level of perception."183 "Was aber ẅar gewesen während all der Zeit, in der er das geworden, was er nun war?--Erstarrung; Öde; Eis; und Geist: Und Kunst!"184. He was isolated, for his bürgerlich mind drove him from the artistic world and his art drove him from the bürgerlich world. He was "ein Bürger, der sich in der Kunst verirrte, ein Bohemien mit Heimweh nach der guten Kinderstube, ein Künstler mit schlechtem Gewissen."185 At long last, he has come to understand this, and with this insight into his true relationship to Iife comes peace. Like Veraguth, the artist in Hesse's Roßhalde, "he recognizes belatedly what he had long refused to

181 o'Neill, p. 295.

182 Hesse, G.S., IV, p. 290.

183 Kenneth Hughes, "Hesse's Use of Gilgamesh-Motifs in the Humanization of Siddhartha and Harry Haller," Seminar: A Journal of Germanic Studies, 5 (1969), 135.

184 Mann, G.W., VIII, p. 336.

185 Mann, G.W., VIII, p. 337. 
acknowledge: that he is by nature an outsider and an obserer, that art is his destiny, and not just his consolation, and that loneliness is his element and not something to be feared." $186 \mathrm{He}$ is to be alone; but life will be there, too. During the final moments of his day of awakening, we read: "Um -ihn war es still und dunkel. Aber von unten tönte gedämpft und wiegend des Lebens süßer, trivialer Dreitakt zu ihm herauf." 18 ?

Tonio writes Lisaveta that "es gibt ein Künstlertum, so tief, so von Anbeginn und Schicksals wegen, daß keine Sehnsucht ihm süßer und empfindenswerter erscheint als die nach den Wonnen der Gewöhnlichkeit."188 He realizes the origins of his own instincts, the irregularities he inherited from the disparities of his solid, bürgerlich father and his sensuous, passionate mother. Tonio states, "Ganz ohne Zweifel, war dies eine Mischung, die außerordentliche Möglichkeiten--und außerordentliche Gefahren in sich schloß."189 It was dangerous, because it gave him extraordinary gifts, and the inherent danger here is discussed by Hesse in his: "Nachwort zu Novalis," Dokumente Seines Lebens und Sterbens" (1924). When speaking of this essay, Mileck suggests:

Hesse proceeded to resolve what in his mind had become the "philistine bourgeois theory that genius

186 Mileck, pp. 85-86.
187 Mann, G.W., VIII, p. 336.
188 Mann, G.W., VIII, p. 337.
189 Mann, G.W., VIII, p. 337. 
is always related to insanity." Genius was not absolutely linked or synonymous with insanity but could easily succumb to it, and again, not because it was something less, but something more than normal. Like neurosis, insanity was only another risk run by the gifted and not an inherent part of their constitution. 190

Tonio's new self-awareness, W.H. Rey declares, shows one of Mann's first attempts to visualize a reconciliation between art and life. The hero, standing between the world of the artist and of the bourgeois, realizes that he must draw on both of them in order to be a true poet. . . . Between excesses of cold intellect and scorching sensuality, however, he feels a nostalgia for the human, the living, the usual. Finally, he comes to understand that this love of mankind, springing forth from the depths of his heart and his soul, raises him above the Bohemian, the literary man, the nothing-but-artist.191

In "Schwere Stunde," Thomas Mann states:

Wer schuf, wie er, aus dem Nichts, aus der eigenen Brust? War nicht als Musik, als reines Urbild des Seins ein Gedicht in seiner seele geboren, lange bevor es sich Gleichnis und Kleid aus der Welt der Erscheinungen lieh? 192

Tonio, too, has now gained insight into this fact: "True objectivity is impossible in art. Only externals can be taken from others; the rest comes from the soul of the poet."193 This is not the only time that Mann has suggested the inner, extraordinary origins of artistic creation. Daemmrich writes, "He also suggested in Lotte in Weimar that for the naive genius the beginning of literary creation lies

190 Mileck, p. 109.

191 Rey, p. 197.

192 Mann, G.W., VIII, p. 378.

193 Neider, p. $447 \mathrm{~A}$. 
shrouded in darkness and that his inspiration remains rooted in the 'fertile soil of the unconscious,' no matter how cautiously and conscientiously he may work."194 Tschol-Za Kim quotes Mann as he talks about Mann's essays over Kunst and Künstler: "Kunst kommt freilich nicht aus Gescheitheit, sondern aus innigeren Tiefen, aus größeren sogar, als diejenigen meinen, die sie bloß für Natur halten: von dort nämlich, wo Natur und Geist nur eines sind."195

Tonio now realizes how much he is like Hamlet the Dane: he has been called to one world, the artistic, although he was born to the other, the bürgerlich world (Aschenbach, too, in "Tod In Venedig," realized "daß seine Natur von nichts weniger als robuster Verfassung und zur ständigen Anspannung nur berufen, nicht eigentlich geboren war."196) He has been isolated from both worlds by upbringing and temperament, but now he realizes that he, and only he, is called upon to express both worlds. Even when Tonio was a youth, Hans Hansen "achtete eine gewisse Überlegenheit an ihm, eine Gewandtheit des Mundes, die Tonio befähigte, schwierige Dinge auszusprechen. . . ."197 Now Tonio knows that this will be his task, and he can achieve security "if

\section{Daemmrich, p. 35.}

195 Thomas Mann, Altes und Neues, Kleine Prosa aus fün Jahrzehnten (Frankfurt, 1961), p. 301, quoted by Kim, p. 88 .

$$
\begin{aligned}
& 196 \text { Mann, G.W., VIII, p. } 451 . \\
& 197 \text { Mann, G.W., VIII, p. } 276 .
\end{aligned}
$$


he accepts his art, if he believes in his mission of making life expressive for the inarticulate."198

Tschol-Za Kim writes, "Im Ganzen genommen herrscht der Dualismus in der Weltauffassung Thomas Manns vor in dem Sinn, daß er die Welt einerseits durch Gott und Natur und anderseits durch den Menschen gestaltet sieht: "Allein mit Gott und Natur ist die Welt nicht ausgesagt, das Menschliche, das Humane gehört mithinein.»"199 Tonio confirms this in his letter to Lisaveta, "where his earlier conviction of the necessity of choosing between two inimical poles is rejected in favor of the necessity of a fusion of the two. . . 200 It is Tonio's capability, his bürgerlich love of the human, the living and the usual, that will breathe life into the distant aloofness of the artistic expression, that will make the poet out of the literary man. Kim writes:

Durch die Iiebe Tonios $\mathrm{zu}$ den Blonden und Blauäugigen entsteht eine gewisse Beziehung zwischen «Kunst» und "Leben», und diese Liebe hat die Wirkung, die eisige Verödung seiner Künstlerexistenz mit menschlicher Wärme zu beleben. . . Somit kann er als Mensch und zugleich auch als Künstler weiterleben, anstatt durch die geistige kälte und Verödung innerlich hohl und zerrissen zu werden. . . Seine Liebe zum «Leben» zerstört nicht mehr sein Künstlertum, sogar im Gegenteil, sie befruchtet es.201

"Was ich getan habe, ist nichts, nicht viel, so gut wie nichts," he writes Lisareta. "Ich schaue in eine unge-
198 wilkinson, p. 26.
$199 \mathrm{Kim}, \mathrm{p} .71$.
200 o'Neill, p. 293.
$201 \mathrm{Kim}, \mathrm{p} .78$. 
borene und schemenhafte Welt hinein, die geordnet und gebildet sein will. . . ."202 Tonio has found his new world,

a world where he is no longer isolated, because he knows now where he belongs. He has gained insight, and his selfawareness has shown him such a world as was described later by Hesse in Demian:

Draußen war die «Wirklichkeit», draußen waren Straßen und Häuser, Mienschen und Einrichtungen, Bibliotheken und Lehrsäle--hier drinnen aber war Liebe und Seele, hier lebte das Märchen und der Traum. Un'd doch lebten wir keineswegs von der welt abgeschlossen, wir lebten in Gedanken und Gesprächen oft mitten in ihr, nur auf einem anderen Felde, wir waren von der Mehrzahl der Menschen nicht durch Grenzen getrennt, sondern nur durch eine andere Art des Sehens. Unsere Aufgabe war, in der Welt eine Insel darzustellen, vielleicht ein Vorbild, jedenfalls aber die Ankündigung einer anderen Möglichkeit zu leben.203

Lisaveta was nearly right in calling Tonio a Bürger. He was inlove with the bürgerlich life, but it was not the bürgerlich feelings that he sought, it was the buirgerlich qualities, the bürgerlich warmth he needed to balance his artistic coolness. He recognizes now that his "tiefste und verstohlenste Liebe gehört den Blonden und Blauäugigen, den hellen Lebendigen, den Glücklichen, Liebenswïrdigen und Gewöhnlichen. "204

The progress that Tonio has made in his life is a result of his newly-gained insight. He at last sees that he 202 Mann, G.W., VIII, p. 338.
203 Hesse, G.S., III, p. 236.
204 Mann, G.W., VIII, p. 338. 
is much as he was even as a child, but now he understands himself. If we look at the final words of his letter to Iisaveta, we see what M.W. Swales has pointed out: "They are a repetition of the words of the narrator that summed up the first section. Tonio's basic psychological state is now as it was then: what is new is his insight into it."205

Tschol-Za Kim suggests:

Die charakteristischen Merkmale des Künstlertums in Tonio Kröger sind, daß Tonio Kröger durch «Neid und Liebe» zum glücklichen Bürger einmal in gewisse Berührung mit dem normalen Leben kommt, und zum anderen «Neid und Liebe» das Mittel werden, durch das die eisige Erstarrung der Künstlerexistenz Tonios gewissermaßen verhindert wird. Dadurch wird es verdeutlicht, daß die «Kunst» nicht unbedingt der unüberwindliche Gegensatz zum «Leben» ist wie bei Detlev Spinell in Tristan oder wie in Die Hongernden. 206 .

The final summing up is a repetition of the narrator's earlier words. This restatement, Swales points out, is significant because it is performed in the present tense: this demonstrates Tonio's new awareness.

Schelten Sie diese Liebe nicht, Iisaweta; sie ist gut und fruchtbar. Sehnsucht ist darin und schwermütiger Neid und ein klein wenig Verachtung und eine ganze keusche Seligkeit.207

205 M.W. Swales, "Punctuation and the Narrative Mode: Some Remarks on Tonio Kröger." Forum for Modern Language Studies, $6(1970), 240$.

$$
\begin{aligned}
& 206 \text { Kim, p. } 75 . \\
& 207 \text { Mann, G.W., VIII, p. } 338 .
\end{aligned}
$$




\section{CHAPTER VI}

\section{CONCLUSIONS}

\section{E.M. Wilkinson suggests:}

This, the aesthetic experience, is a special kind of awareness of the universe. It comes in those moments when we experience things and people, not in their bearing on our own needs and affairs, but for their own sake. They are then no longer simply particular people, things, or events. We see through their accidental bounds and discover immense vistas beyond. 208

These are the moments of artistic "seeing" of the universe. For the non-Künstler, the moments are rare. We are suddenly transported beyond this earth to the icy realm of artistic creation; this is the moment of comprehension of the inner workings of the universe. This is the moment we "see" the multi-dimensional man and the totality of the world. We understand the words of Hermann Hesse:

Ich glaube nämlich an nichts in der welt so tief, keine andre Vorstellung ist mir so heilig wie die der Einheit, die.Vorstellung, daß das Ganze der Welt eine göttliche Einheit ist und daß alles Leiden, alles Böse nur darin besteht, daß wir einzelne uns nicht mehr als unlösbare Teile des Ganzen empfinden, daß das Ich sich zu wichtig nimmt. Viel Leid hatte ich in meinem Leben erlitten. . . aber immer wieder war es mir gelungen, mich zu erlösen - . die Einheit zu fühlen, den Zweispalt zwischen Innen und Außen, zwischen Ich und Welt als Illusion $\mathrm{zu}$ erkennen und mit geschlossenen Augen willig in die Einheit einzugehen.209.

Wilkinson, p. 22 .

209 Hesse, G.S., IV, pp. 63-64. 
Moments of aesthetic experiences are the moments that distinguish the Kunstler, for it is the Künstler's task to take such moments and "shape" them into art. And because it is the Künstler's task to "see" and to "shape," his life is destine to be different, to "see" more clearly and to "feel" deeper than ordinary individuals. Even the intellectual with his specialized knowledge is not subject to the same forces that move the artist. Hesse explains in Unterm Rad:

Ihm gefiel das an der Mathematik, daß es hier keine Irrungen und keinen Schwindel gab, keine Mïglichkeit, $\ddot{v}$ om Thema abzuirren und trügerische Nebengebiete zu streifen. . . Aber wenn beim Rechnen auch alle Resultate stimmten, es kam doch eigentlich nichts Rechtes dabei heraus. Die mathematischen Arbeiten und Lehrstunden kamen ihm vor wie das Wandern auf einer ebenen Landstraße; man kommt immer vorwärts, man versteht jeden Tag etwas, was man gestern noch nicht verstand, aber man kommt nie auf einen Berg, wo sich plötzlich weite Aussichten auftaten. 210

But along with the ability to reach great heights, to the Künstler also comes suffering, dissatisfaction with seeing the imperfect, a descent into the depths of despair. To be a Künstler is to be different, to be outside normal life, to be lonely. To be a künstler is more than merely knowing how to do something. As the Immortals describe the type of men the Steppenwolves are, "sie sind nicht Helden oder Künstler oder Denker in der Art, wie andere Richter, Ärzte, Schuhmacher oder Lehrer sind. . . "2ll Mann tells us in "Schwere Stunde":

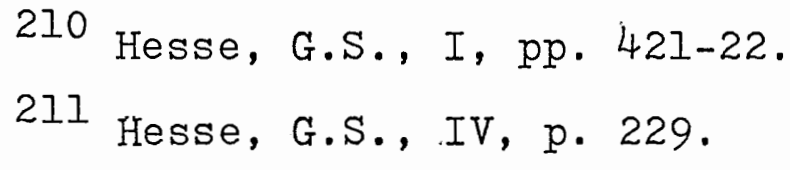


Denn das Talent. . . ist nicht ohne weiteres ein Können. In der Wurzel ist es Bedürfnis, ein kritisches Wissen um das Ideal, eine Ungenügsamkeit, die sich ihr Können nicht ohne Qual erst schafft und steigert. . . . Bescheiden, geduldig denken von dem, was man trug! Und wenn nicht ein Tag in der Woche, nicht eine Stunde von Leiden frei war--was weiter?212

And yet there are rewards which make all the suffering bearable. The ability to see into the depths also enables one to reach the heights. Wilkinson claims, "The joy it brings outweighs the pain. And even though awareness may make the pains of suffering sharper, it yet removes from it the destructive quality of blind sorrow. . . 'Dumpfheit,' mere hollow existence, Goethe called such blind living, and preferred 'a life eternally resonant,' whether it brought him joy or sorrow."213 The heights and depths are a necessary part of the artist's existence. Hesse illustrates:

Manchmal scheint mir, die schale habe sich gesenkt und meine guten Stunden seien $\mathrm{zu}$ selten und $\mathrm{zu}$ wenig gut, um die üblen noch aufzuwiegen. Zuweilen finde ich im Gegenteil, dass ich Fortschritt gemacht habe, dass die guten Stunden zu- und die bösen abgenommen haben. Was ich niemals wïnsche, auch in den schlechtesten stunden nicht, das ist ein mittlerer Zustand zwischen Gut und Schlecht, so eine laue erträgliche Mitte. Nein, lieber noch eine Übertreibung der Kurve--lieber die Qual noch böser, und dafür die seligen Augenblicke noch um einen Glanz reicher!214

Mann himself writes of the rewards of the suffering:

Größe! Außerordentlichkeit! Welteroberung und Unsterblichkeit des Namens! Was galt alles Glück der ewig Unbekannten gegen dies Ziel? Gekannt sein, --gekannt und geliebt von den Völkern der Erde:

\footnotetext{
212 Mann, G.W., VIII, pp. 375-76.

213 Wilkinson, p. 23.

214 Hesse, G.S., III, p. 421.
} 
Schwatzet von Ichsucht, die Ihr nichts wißt von der Süßigkeit dieses Traumes und Dranges! Ichsüchtig ist alles Außerordentliche, sofern es leidet. $215^{\circ}$

Thus the suffering of the Künstler, like the suffering of the intellectual, is caused by his refusal to compromise in order to avoid the extremes of life, in order to live a safe, normal, bland existence. Unlike the intellectual, however, the Künstler acts with a positive goal: he endures the sufferings in order to experience the joys. The inteltectual has no such drive. His despair can only lead to neuroses.

But just as the common Bürger does not distinguish between the "Künstler" and the "Literat," neither does he distinguish between the Künstler and the intellectual in their divergence from the normal life. He knows only that they both reject the ordinary world in their search for the ideal. The intellectual, however, realizes that the struggle is hopeless, that the goals will not be reached, and suffers. The Künstler realizes that the goals may not be reached, but also realizes that they are, indeed, goals, and therefore ought to be attempted. It is only abandonment of the struggle that brings despair. As Hermine tells the Steppenwolf:

Dein Leben wird auch dadurch nicht flach und dumm, wenn du weißt, daß dein Kampf erfolglos sein wird. Es ist viel flacher, Harry, wenn du für etwas Gutes und Ideales kämpfst und nun meinst, du müssest es auch erreichen. Sind denn Ideale zum Erreichen da? Leben wir denn, wir Menschen, um den Tod abzuschaf-

215 Mann, G.W., VIII, p. 376. 
fen? Nein, wir leben, um ihn zu fürchten und dann wieder zu lieben, und gerade seinetwegen glüht das bißchen Leben manchmal eine Stunde lang so schön.216

There are those, then, who know what it is to shun compromise, to suffer the unendurable because of the magnificance of the ideal. They know the burdens, as Goethe did, of the call, "Immer streben!" and they also know the awareness this striving brings, which Goethe expressed in Wilhelm Meisters Lehrjahre:

Wer nie sein Brot mit Tränen aß,

Wer nie die kummervol. Ien Nächte

Auf seinem Bette weinend sass,

Der kennt euch night, ihr himmlischen Nächte.

There is an inherent danger, however, in being a

Künstler. It is the danger brought about by the necessary artistic isolation, the feeling that you are "different," the knowing of the struggle to reach. the ideal. The danger lies in the exaggerated sense of failure that comes from the awareness of your isolation. This is the danger which Tonio Kröger faced, the problem he had to overcome. Wilkinson claims, "His inner loneliness springs rather from his deep sense of failure as a human being. At some point in an experience words become more exciting to him than the experience itself. Even in an intimate relationship he fears he may be sidetracked by the artist's eye. . ."217 Tonio sees this as the burden of the artist: "Hellsehen noch durch den Tränenschleier des Gefühls hindurch, erkennen, merken,

216 Hesse, G.S., IV, pp. 308-09.

217 Wilkinson, p. 24. 
beobachten und das Beobachtete lächelnd beiseite legen müssen noch in Augenblicken, wo Hände sich umschlingen, Lippen sich finden, wo des Menschen Blick, erblindet von Empfindung, sich bricht,--es ist infam, Lisaweta, es ist niederträchtig, empörend. . . aber was hilft es, sich zu empören?"2l8 This is the loneliness of the Künstler: the knowledge that he is not normal, but extraordinary, unhuman.

Tonio Kröger was a "marked man" from his early youth. His talents, his awareness pushed him along a path, and yet his awareness that he was "different" caused him pain and anguish. He had glimpsed an ideal and thought he knew the "right" path for him to follow. The others all followed a "wrong" path, and yet they all seemed happy and fulfilled. Was he mistaken in his dreams of life, would the others be shown in the end to be right, would his path turn out to have been a mistake? Tonio's worry was that if he didn't sacrifice a part of himself to become "normal," his whole life might turn out in the end to be completely worthless.

Tonio"s long journey on that "Weg nach Innen" enables him to develop his talents for self-examination, for a dispassionate examination of life, and those talents eventually bring self-awareness and self-affirmation. The Künstler brings these talents to his creativity; Tonio brings them into his life as well, and this gives him an extra dimension. Tonio's cold and desolated trip through the realm of 218 Mann, G.W., VIII, pp. 300-01. 
art gives him the ability to look beyond "right". and "wrong." The non-introspective, "normal" person never gains this extra dimension; the person who has it can never be normal. We understand why "wenn er irreging, so geschah es, weil es für etliche einen richtigen Weg überhaupt nicht gibt." 219 At last Tonio was able to admire that which he came to realize he himself could never possess: the "human" qualities of the "normal" person.

Tonio worried because he could not remain on the "right," the normal path, and felt guilty because the people he felt different from could. He finally learns that it is not the path which is "wrong" or "right": there are many paths, and some are trodden more often than others. Because of who and what he is, the right path for the "normal" person, the person who has not begun that "Weg nach Innen," is not right for him. In the end, he sees that the paths are not right and wrong, that each individual must seek his own path; and that if someone like himself must follow an untrodden path; it can still lead to a life as full and as rich as the paths taken by those who do not possess his extra dimension. This self-awareness does not lead to paradise. What it does is to enable Tonio to look forward to the future with hope and affirmation instead of with fear and trepidation and resignation. "Heim kommt man nie," says Frau Eva in Hesse's Demian. "Aber wo befreundete Wege zu219 Mann, G.W., VIII, p. 288. 
sammenlaufen, da sieht die ganze welt für eine Stunde wie Heimat aus." 220

Tonio is a loner, and he remains a loner, for he has not yet met others in his new view of the world who have his talents and his insights. We may ponder whether he will remain a unique individual in a world of his own, or whether indeed there are other kindred souls out there with whom he will finally be fulfilled. To deny this hope is to see Tonio's isolation as merely an extreme extension of the isolation of the Künstler. To affirm Tonio's hope is to see within Thomas Mann's story this further premise: that the man who cannot adapt to the "real". world is a rare individual, and yet there is a humanity on this earth that consists of these rare individuals.

To see the story as more than a tale of an isolated Künstler's problematic life requires that the reader himself be aware of how it feels to be an outsider. The problem is similar to showing the unbeliever the validity of the Iife of a true Christian: the unbeliever is incapable of seeing without "faith." Just so is it hard for one who has not taken Tonio's path to be able to understand his viewpoint. Still, whereas the religious person is convinced of the righteousness of his world and knows it is possible for all to join him there, the isolated individual becomes convinced of the righteousness, of his world only 
when he understands that most people are incapable of ever being in it.

The world of the isolated individual, then, is of necessity a lonely world. For the Kunstler who endures the sufferings of personal isolation, as we have seen in Tonio Kröger, the loneliness can be intense. In order to overcome this loneliness, in order to understand himself, in order to understand the world around him, the isolated Künstler expresses himself through his craft. The lonely writer, the "isolated Iiterat," then, is a special individual: his themes are both literary and personal. Thus the existence of such works as Tonio Kröger, Steppenwolf, and Die Leiden des jungen Werther, with such closely allied themes, shows us that they can be treated as more than mere artistic endeavors whose devices are attributable to standard literary sources. These works are not merely artistically created fiction. They represent an effort by an isolated individual to affirm and to demonstrate the validity of his own life. By such efforts, the author can thereby affirm the validity of such a life to someone who might be struggling with such problems of his own and who needs encouragement for his own convictions if he is not to succumb to the pressure of the common and withdraw from his full possibilities.

Sometimes, it merely takes someone like Hermann Hesse, who has been there, to say:

Wohl dem Bauern! Wohl dem Besitzenden und Seßhaften, dem Treuen, dem Tugendhaften: Ich kann ihn lieben, ich kann ihn verehren, ich kann ihn beneiden. Aber ich habe 
mein halbes Ieben daran verloren, seine Tugend nachahmen $\mathrm{zu}$ wollen. Ich wollte sein, was ich nicht war. Ich wollte zwar ein Dichter sein, aber daneben doch auch ein Bürger. Ich wollte ein Künstler und Phantasiemensch sein, dabei aber auch Tugend haben und Heimat genießen. Lange hat es gedauert, bis ich wußte, daß man nicht beides sein und haben kann, daß ich Nomade bin und nicht Bauer, Sucher und nicht Bewahrer. Lange habe ich mich vor Göttern und Gesetzen kasteit, die doch für mich nur Götzen waren. Dies war mein Irrtum, meine Qual, meine Mitschuld am Elend der Welt. Ich vermehrte Schuld und Qual der welt, indem ich mir selbst Gewalt antat, indem ich den Weg der Erlösung nicht zu gehen wagte. Der Weg der Erlösung führt nicht nach links und nicht nach rechts, er führt ins eigene Herz, und dort allein ist Gott, und dort allein ist Friede.2えl

Through artistic expression, Thomas Mann was able to affirm the validity of his own life, and he expressed this over and over. We know there is hope, for we read in Tonio

\section{Kröger:}

Ja, wie damals war es, und er war glücklich wie damals. Denn sein Herz lebte.222

221 Hesse, G.S., III, p. 388.

222 Mann, G.W., VIII, p. 336. 


\section{A SELECTED BIBLIOGRAPHY}

Angell, Joseph Warner, ed. The Thomas Mann Reader. New York: Alfred A. Knopf, 1950 .

Assmann, Dietrich. "Faustus Junior: Thomas Mann und die mythische Identifikation." Neuphilologische Miterteilungen, 72 (1971), 549-53.

Bauer, Arnold. Thomas Mann. Trans. Alexander and Elizabeth Henderson. New York: Frederick Ungar, 1971.

Baron, Frank. "Sensuality and Morality in Thomas Mann's Tod in Venedig." Germanic Review, 45 (1970), 115-25.

Basilius, H.A. "Thomas Mann's Use of Musical Structure and Techniques in Tonio Kröger." 19 (1945), 284-308.

Berendsohn, Walter, E. Thomas Mann: Artist and Partisan in Troubled Times. Trans. George C. Buck. University, Alabama: University of Alabama Press, 1973.

Boulby, Mark. Hermann Hesse: His Mind and Art. Ithaca: Cornell University Press, 1967.

Bräutigam, Kurt. Thomas Mann: Tonio Kröger, Interpretiert von Kurt Bräutigam. 2. Auflage. Mïnchen: R. Oldenbourg Verlag, 1974.

Brown, Calvin S. "A Mixed Bag on Thomas Mann." Journal of Modern Literature, I (1971), 430-33.

Bürgin, Hans, and Hans-0tto Mayer. Thomas Mann: Eine Chronik seines Lebens. Frankfurt/M.: Fischer Verlag, 1965.

Burkhard, Arthur. "Thomas Mann's Treatment of the Marked Man." PNLA, 43 (1928), 561-68.

Casebeer, Edwin F. Hermann Hesse. New York: Thomas Crowell, 1972 .

Church, Margaret. "Death in Venice: A Study in Creativity." College English, 23 (1962), 648-51.

Cleugh, James. Thomas Mann: A Study. 1933; rpt. New York: Russell and Russell, 1968. 
Consigne, Scott. "Aschenbach's 'Page and a Half of Choicest Prose': Mann's Rhetoric of Irony." Studies in Short Fiction, 14, No. 4 (1977), 359-67.

Daemmrich, Horst.S. "Mann's Portrait of the Artist: Archetypal Patterns." Bucknell Review, 14, No. iii (1966), $27-43$.

- "Thomas Mann's Perception of Self-Insight." Papers on Language and Literature, 13 (1977), $270-82$.

Dyson, A.E. "The Stranger God: Death in Venice." Critical Quarterly, 13 (1971), 5-20.

Ellis-Jones, R.B. "The Place of the Bürger in Thomas Mann's Essays." German Life and Letters, 23 (1970), 347-55.

Exner, Richard. "Reading Thomas Mann: An Appreciation." Books Abroad, 49 (1975), 480-83.

Fass, Barbara F. "The Little Mermaid and the Artist's Quest for a Soul." Comparative Literature Studies, 9 (1972), 291-302.

Field, G.W. "Hermann Hesse: Polarities and Symbols of Synthesis." Queens Quarterly, 81 (1974), 87-101.

Friederich, Werner P. An Outline History of German Iiterature. 2nd ed., 1961; rpt. New York: Barnes and Noble, 1970.

Glebe, William V. "The Artist's 'Disease' in Some of Thomas Mann's Earliest Tales." Books Abroad, 39 (1965), $261-68$.

"The 'Diseased' Artist Achieves a new 'Health': Thomas Mann's Lotte in Weimar. Modern Language Quarterly, 22 (1961) 5 5-62.

Goethe, Johann Wolfgang von. Eckermann: Gespräche mit Goethe. Ed. Hans Timotheus Kroeber. Weimar: Gustav Kiepenheuer Verlag, 1918. 1950thes Werk. Hamburg: Christian Wegner Verlag,

Greene, Bob. "Thieves Today Lacking Finesse." The Oregonian, 4 May 1979, p. D4, col. 1.

Hatfield, Henry. Thomas Mann. Rev. ed. New York: New Directions, 1962. 
Hellersberg-Wendriner, Anna. "The Essence of Thomas Mann." Commonweal, 62 (1955), 583-86.

Hesse, Hermann. Gesammelte Schriften. Frankfurt/M. : Suhrkamp Verlag, 1957.

Hoffman, Fernand. "Krankheit und Kreise als Lebenssteigerung: Zur Weltphilosophie des Lebensschändlichen bei Thomas Mann." Stimmen der Zeit, 189 (1972), $248-65$.

Hughes, Kenneth. "Hesse's Use of Gilgamesh-Motifs in the Humanization of Siddhartha and Harry Haller." Seminar: A Journal of Germanic Studies, 5 (1969), $129-40$.

Kamenetsky, Christa. "Dichter vs. Literat: Thomas Mann's Ironic Views of the Literary Man." College Language Association Journal, 14 (1971), 420-31.

"Thomas Mann's Concept of the 'Bürger'." College Language Association Journal, 5 (1962), $184-94$.

Kelly, John Alexander, ed. Tonio Kröger: Novelle von Thomas Mann. New York: Apple ton-Century-Crofts, 1959.

Kim, Tschol-Za. "Natur und Geist bei Thomas Mann." Colloquia Germanica, i-ii (1975), 69-90.

Kirchberger, Lida. "Death in Venice and the Eighteenth Century." Monat:shefte, 58(1966), 321-34.

- "Popularity as a Technique: Notes on Tonio Kröger." Monatshefte, 63 (1971), 321-34.

Kohut, Heinz. "'Death in Venice' by Thomas Mann: A Story About the Disintegration of Artistic Sublimation." Psychoanalytic Quarterly, 26 (1957), 206-28.

Latta, Alan D. "The Mystery of Life: A Theme in Der Zauberberg." Monatshefte, 66 (1974), 19-32.

Lauschus, Leo. "Thomas Mann: Der Weg zum Friedhof:" Der Deutschunterricht, 10, No. v (1958), 66-81.

Lehnert, Herbert. "Another Note On 'Motus Animi Continuus' and the Clenched-Fist-Image in Der Tod in Venedig." German Quarterly, 40 (1967), 452-53.

Mann, Golo. Thomas Mann, 1875/1965; Memories of My Father. Bonn: Inter Nationes, 1965. 
Mann, Thomas. Briefe, 1937-1947. Ed. Erika Mann. n.p.: S. Fischer Verlag, 1963. - Fi Gesammelte Werke in zwölf Bänden. Oldenburg: S.

McNamara, Eugene. "Death in Venice: The Disguised Self." College English, 24 (1962), 233-34.

Métraux, G.S. "The Psychic Evolution of Modern Man: Steppenwolf by Hermann Hesse (1927)." Trans. Aline B. Werth. Cultures, 4, No. 4 (1977), 36-47.

Michels, Volker, ed. Materialien zu Herman Hesses «Der Steppenwolf». Frankfurt/M.: Suhrkamp, 1972.

Mileck, Joseph. Herman Hesse: Life and Art. Berkeley: University of California Press, 1978.

Neider, Joan Merrick. "Thomas Mann's Artistic Theory, 19001925." DAI, 32 (1971), 447A (Columbia University).

Nietzsche, Friedrich. Werke in drei Bänden. Herausgegehen von Karl Schlechta. Miunchen: Carl Hansen Verlag, 1960 .

Nündel, Ernst. "Der Bogen und die Leyer: Thomas Manns Äußerungen zur künstlicher Tätigkeit." Der Deutschunterricht, 21 , No. ii (1969), 42-53.

O'Neill, Patrick. "Dance and Counterdance: A Note on 'Tonio Kröger'." German Life and Letters, 29 (1976), 291-95.

Reed, R.J. Thomas Mann: The Uses of Tradition. Oxford: The Clarendon Press, 1974.

Rey, William H. "Tragic Aspects of the Artist in Thomas Mann's Work." Niodern Language Quarterly, 19 (1958), 195-203.

- "A Tragic View of Thomas Mann." Modern Language Quarterly, 20 (1959), 167-72.

Schiller, Friedrich. Sämtliche Werke. 4 th ed. n.d.; rpt. München: Carl Hansen Verlag, 1965.

Schmid, Max, Hermann Hesse. Zürich: Fritz and Wasmuth, 1947 .

Schmidt, Willa. "The 'Wiedersehen' Motif in the Works of Thomas Mann." Monatshefte, 65 (1973), 144-60. 
Swales, M.W. "Punctuation and the Narrative Mode: Some Remarks on Tonio Kröger." Forum for Modern Language Studies, 6 (1970), 325-42.

Telier, Gertrude E. "Virata or the Eyes of the Undying Brother and Stefan Zweig's Thought." Germanic Review, $27(1952), 31-40$.

Wilkinson, E.M. "Tonio Kröger: An Interpretation." In Tonio Kröger. Ed. E.M. Wilkinson. Basil Blackwell, 1944. Rpt. with slight modifications in Thomas Mann: A Collection of Critical Essays. Englewood Cliffs, $\bar{N} . J .:$ Prentice-Hall, 1964. Pp. 22-34.

Wilson, Eric. "The Private Games of Thomas Mann." German Quarterly, 47 (1974), 1-12.

Wilson, Kenneth G. "The Dance as Symbol and Leitmotiv in Thomas Mann's Tonio Kröger." Germanic Review, 29 $(1954), 282-87$.

Witthoft, Brucia. "Tonio Kröger and Muybridge's 'Animals in Motion." Modern Language Review, 62 (1967), 459-61.

Woodward, Anthony. "The Figure of the Artist in Thomas Mann's Tonio Kröger and Death in Venice." English Studies in Africa, $9(1966), 158-67$.

Yates, W.E. Grillparzer: A Critical Introduction. Cambridge: University Press, 1972.

Zeller, Bernhard. Portrait of Hesse. Trans. Mark Hollebone. New York: Herder and Herder, 1971.

Ziolkowski, Theodore. "Hermann Hesse's 'Steppenwolf': A Sonata in Prose." Modern Language Quarterly, 19 (1958), 115-33.

- "The Quest for the Grail in Hesse's Demian." Germanic Review, 49 (1974), 44-59.

Zucker, A.E. Ibsen: The Master Builder. New York: Henry Holt, 1929. 